\title{
The Judicial Confirmation Process: The Difficulty with Being Smart
}

\author{
John R. Lott, Jr.*
}

\begin{abstract}
Republicans and Democrats both complain about the difficulty in getting judges confirmed when it is their nominees who are up for confirmation, but there has not been any systematic study of either how much worse this problem has gotten or what its causes might be. Several patterns do emerge for data from the beginning of Jimmy Carter's administration through the end of George W. Bush's first term. It is taking even longer for confirmation, and the more important the position, the longer confirmation takes. Among the findings, it took almost three times longer for circuit court judges to be confirmed under George W. Bush than under his father. The rate of confirmation for circuit court judges has also fallen while the confirmation rate for district court judges has risen. Higher-quality judges, measured by their output once they are on the court (e.g., number of citations to their opinions or number of published opinions), take much longer to get confirmed. Evaluated at the mean judicial quality, a 1 percent increase in judicial quality increases the length of the confirmation process by between 1 and 3 percent. Many of the traditional ex ante measures of judicial quality such as where the judge went to law school or a nominee's American Bar Association (ABA) ratings add little if anything to predicting how well he or she will do on the bench. A 1 percent increase in polarization in the voting differences between the political parties in the Senate produces between a 3 and 10 percent increase in the length of the confirmation process for circuit court judges. Even after accounting for differences in nominee quality, Republican circuit court nominees also have significantly lower ABA ratings than Democratic nominees and ABA scores do not affect the length of circuit court confirmations.
\end{abstract}

\section{INTRODUCTION}

Many perceive the judicial nomination process as broken. Democrats "bitterly complained" about the difficulties in confirming nominees during President Clinton's administration and Republicans have likewise complained

\footnotetext{
*American Enterprise Institute, 1150 17th St., NW, Washington, DC 20036; email: jlott@aei.org.
} 
about "inexcusable" delays during President George W. Bush's first term in office (Carney 1997; Hatch, Kyl, Thurmond, Brownback, Grassley et al. 2001; Chicago Daily Law Bulletin 2000). Of course, both sides come up with explanations when they are the ones being blamed for delays (Leahy 2001).

Some politicians, including Clinton, have made even more explosive claims and alleged that "delays in approving Clinton's minority and female judges showed racist and sexist tendencies in the Senate" (Holland 2000b; Ross 2000) or that it is an "appointment system that continues to favor white men significantly and is so dominated by politics and paybacks that minorities are twice as likely to be rejected as whites" (Biskupic 2000). During the Clinton Administration, Democrats claimed that the "delay of judicial nominations [during the last two years of the Clinton Administration] is unprecedented" and being done for "political reasons" (Hartley 2000; Holland 2000b). ${ }^{1}$

The confirmation process seems to have changed during President George W. Bush's administration as Democratic senators began filibustering judicial nominations and requiring 60 votes for confirmation. ${ }^{2}$ During Bush's first term, 10 nominees to the circuit court were blocked from a floor vote and another five were stopped by the mere threat of a filibuster (Wall Street Journal 2004). Seven of those nominees who were filibustered were able to pick up only between one and two Democratic senators in cloture votes, leaving them far short of the 60 votes needed. ${ }^{3}$ President Bush responded by making recess appointments for Alabama Attorney General William Pryor and Judge Charles Pickering of Mississippi to the federal circuit court.

Two measures are used here to illustrate how the nomination process has changed: the number of days between nomination and confirmation and

\footnotetext{
${ }^{1}$ An irony for these last judicial nominees who were approved by Congress is that " $[\mathrm{i}] \mathrm{n}$ an endof-session twist, Democrats are holding up President Clinton's federal judicial nominations in the Senate hoping to win additional approvals for other judges."

${ }^{2}$ McGinnis and Rappaport (forthcoming) provide a brief historical discussion of judicial filibusters along with a detailed theoretical discussion of their impact on judicial selection. See also Stolberg (2004).

${ }^{3}$ As of September 28, 2004, there had been a total of 20 cloture votes on the nominations of Miguel Estrada, Priscilla Owen, Charles Pickering, Carolyn Kuhl, Janice Rogers Brown, William Pryor, Bill Myers, Henry Saad, Richard Griffin, and David McKeague. Another five nominations for Terry Boyle, Susan Neilson, William Haynes, Brett Kavanaugh, and Tom Griffith had been threatened with filibusters. Republican Policy Committee (2004).
} 
the confirmation rate. Both help capture the costs of going through the nomination process. Long confirmation processes, even if eventually resulting in confirmation, can dissuade potential candidates from even accepting the nomination, as their lives are essentially put on hold while the process drags on. Although occasionally nominees may withdraw during the process, most potential nominees presumably value avoiding bitter confirmation fights altogether. Fights that end in defeat impose significant costs on the nominees and only very rarely provide him or her with any real benefits from the notoriety the nominee has achieved. Obviously, unless the position is made more prestigious as a result of the greater scrutiny, the greater the cost of obtaining the position, the fewer will seek it, thus lowering the quality of the pool of nominees.

Given the economic and moral regulatory issues before the courts, it is not surprising that the nomination battles are so contentious. As recent evidence from Sunstein, Schkade, and Ellman (2003:48) indicates, with few exceptions such as "criminal appeals, takings, and federalism," the political affiliation of circuit court judges predicts how they will vote on cases, ${ }^{4}$ though the effect is relatively weak since it only applies "to published opinions and ignores the vast bulk of unanimous unpublished dispositions, and even in published opinions the effect is weak (most are unanimous)."5

The results shown below indicate that neither Democrats nor Republicans have "clean hands" in this debate, and that the problem has been getting progressively worse over time. Both sides carefully pick which numbers to emphasize in the debate. For example, the new Democratic minority leader Harry Reid argues that during President George W. Bush's first term, "[w]e have approved for the president of the United States 204 judges the last four years. We've turned down 10. Even in modern math, that's a pretty good deal" (Mann 2005). These numbers exclude those nominees who never made it to the floor for a vote and it lumps together both district and circuit court nominees. In contrast, Republicans emphasize the confirmation rate for circuit court judges, who have been confirmed at much lower rates. The choice of which numbers the different parties emphasized

\footnotetext{
${ }^{4}$ Posner and De Figueiredo (2004) provide evidence on judicial voting for the International Court and see Linquist, Yalof, and Clark (2000) for evidence regarding Supreme Court nominees.
}

${ }^{5}$ Quote from personal correspondence with Judge Frank Easterbrook. 
was reversed during the last four years of the Clinton Administration. A careful examination indicates that over the last couple of administrations, while the confirmation rate of circuit court judges has fallen, the confirmation rate of district court judges has risen.

This article represents the first empirical study to systematically describe how the length of the nomination process has changed over time as well as how that process has been applied against Republican and Democratic administrations. ${ }^{6}$ Obviously, many factors, such as the quality of nominees, have to be taken into account. The timing of these changes, as well as what factors can explain them, remain to be examined.

\section{Existing Literature}

Several papers have systematically analyzed the length and confirmation rate of the judicial confirmation process (Bell, 2002; Binder \& Maltzman, 2002; Nixon \& Goss, 2001). These three papers concentrate on circuit court nominees. Bell looks at the nomination process of federal circuit court nominees from 1979 to 1998; Binder and Maltzman from 1947 to 1998; and Nixon and Goss from 1892 to $1996 .{ }^{7}$ All of them find that divided political control of

\footnotetext{
${ }^{6}$ The previous discussions that I know of are provided by Bell (2002:592), Hartley and Holmes (2002:270-73), and Sheldon Goldman (2003). Although he does not estimate any regressions that attempt to control for factors that are changing over time, Goldman provides the most comprehensive discussion of the length of the confirmation process to date by listing the average length of confirmations by Congress from 1977 to 2002. He conjectures that the last year of a presidential administration makes confirmations more difficult and he mentions the importance of divided control between the presidency and the Senate, but no systematic empirical tests are provided. Bell spends only a couple of sentences stating that after 1995 "the number of days between nomination and confirmation has increased dramatically. Today, many nominees wait between 200 and 300 days for a confirmation." Hartley and Holmes provide a description of the increase in mean times to confirmation from President Nixon to the 105th Congress under President Clinton, but no systematic regressions are run and no discussions of statistical significance are provided. Stratmann and Garner (2004) run regressions that explain the length of the judicial confirmation process, but they do not see how the process is changing over the two administrations that they examine, separate out district and circuit court nominees, nor include anything other than $\mathrm{ABA}$ rating and prior judicial experience to see how different quality judges and treated. Lott (2001) examines other aspects of the judicial confirmation process.

${ }^{7}$ There are some puzzles with the Nixon and Goss study. For example, while they claim to have examined all federal appeals court vacancies from 1892 to 1996, there are only 395 replacement nominees in their sample. By contrast, this study has 297 appointments from 1977 through the end of 2004.
} 
the Senate and presidency has an important impact on how long it takes to confirm a judge. For example, Binder and Maltzman find that confirmation rate at any point in time twice as high as when the same party controls both the presidency and the Senate.

There are some differences in what these studies examine. Bell finds that the impact of a presidential election year and importance of interest groups, as well as how well female and minority nominees do, all have different impacts when government is divided. Binder and Maltzman also claim (2002:197) that the Senate "does not treat critical nominations differently than other nominations, all else equal." They measure how critical a nomination is by looking at how ideologically divided a circuit court is. Nixon and Goss claim that female and minority nominees, as well as nominees to fill a vacancy created by death, take considerably less time to get confirmed.

These papers are interesting, but none of them systematically break down how the confirmation process is changing over time, nor do they account for the nominees' quality beyond the American Bar Association (ABA) rating for nominees, which, given the perceived biases of the ABA, could mean something quite different for Republican and Democratic nominees. Also, none of these estimates account for geographical or time differences in the confirmation process. ${ }^{8}$

McCarty and Razaghian (1999) study the confirmation process of nonjudicial executive branch nominations from 1885 to 1996. For cabinet officials, the length of the nomination process is affected by divided government (presidency and Senate controlled by different parties) as well as the size of the ideological gap between the two parties in the Senate, though divided government does greatly lengthen the process for lower-level positions. They also find that nominations go through more quickly early in a president's term, and that Republican as well as Justice Department nominations in general tend to take relatively long. In a rough comparison between the preand post-New Deal periods, they do not find any differences in the length of the confirmation process over time.

There is also work on how the confirmation rate has changed over time. For example, Hartley and Holmes (2002) find that the fraction of lower court nominees confirmed does not change when party control differs between the White House and the Senate, though they do not account for other factors that may affect judicial selection.

\footnotetext{
${ }^{8}$ Nixon and Goss do account for a District of Columbia Circuit Court dummy but do not do anything else.
} 


\section{DATA}

Data were collected on nominees who were publicly announced, whether they were confirmed or defeated or withdrawn. The so-called Lower Federal Court Confirmation Database was used for information on district and circuit court judges from 1977 to 2000 to find the nomination date, whether the nominee was confirmed, the confirmation date, the court to which the nominee was appointed, and the nominee's gender and race. ${ }^{9}$ Information on the judicial nominees from 2001 through the end of 2004 was obtained from the Office of Legal Policy in the Department of Justice. ${ }^{10}$

Biographies on federal judges from the Federal Judicial Center provided information on race, whether the nominee had been a federal or state judge, graduate from a top-10 law school, had served on the law review, and the incumbent judge for all judges from 2001 on, and this information was used to fill in gaps prior to 2001. ${ }^{11}$ ABA ratings for judges from 1989 through early 2004 are from the American Bar Association. ${ }^{12}$ Previous data for earlier years are available from the Lower Federal Court Confirmation Database. The data for the last part of 2004 were obtained from the Senate Judiciary Committee. ${ }^{13}$ Short biographies on all Clinton nominees (including those not confirmed) are available from the Clinton Presidential Materials Project. ${ }^{14}$ Lexis-Nexis searches were used extensively to fill in missing race and political affiliation information. Such searches were also extensively used to find information on nominees who were not confirmed. ${ }^{15}$

In a series of papers, Landes, Lessig, and Solimine (1998) and Stephen Choi and Mitu Gulati (2003, 2005) have developed various objective meas-

\footnotetext{
${ }^{9}$ Available at $<$ http://bingweb.binghamton.edu/ martinek/confirmation.htm $>$. Since we first used the website it has been updated.

${ }^{10}$ Available at $<\mathrm{http}: / /$ www.usdoj.gov/olp/judicialnominations.htm $>$.

${ }^{11}$ Available at $<$ http://www.fjc.gov/>.

${ }^{12}$ Available at $<$ http://www.abanet.org/scfedjud/home.html>.

${ }^{13}$ The nominations clerk who helped us was Swen Prior (202-224-5225).

${ }^{14}$ Available at $<$ http://clinton6.nara.gov $>$.

${ }^{15}$ Leonard Leo at the Federalist Society provided some data on about 20 percent of the appeals court judges studied here.
} 
ures of judicial quality. Landes et al. focus on the rates that judges are cited outside and inside their circuits both in terms of their total influence (total citations adjusted for experience) and average influence (citations per published opinion). They generate these ranking from regressions that account for such factors as the judge's tenure, the number of opinions authored each year by the judge, and the total number of published opinions in the courts of appeals each year, as well as whether the judge is chief judge, on senior status, and/or retired. Choi and Gulati's (2003) method is simpler but covers more characteristics. Judicial rankings are based on how frequently judges are cited outside their circuit, the number of opinions they write, and their judicial independence (whether judges vote in accordance with other judges nominated by the same political party). ${ }^{16}$ There are 11 different components to their "composite" index and it is important to try to disaggregate them.

These two measures cover different time periods. Landes et al. cover judges on the courts of appeals in 1992 who had at least six years of experience by 1995 (for my purposes, nominees from the Carter, Reagan, and Bush I Administrations), while the Choi and Gulati indexes focus on published opinions of judges from 1998 to 2000 who were appointed prior to January 1, 1998 (the Carter through first three-quarters of the Clinton Administrations). Unfortunately, these dates, especially for the Landes et al. data, make us unable to use this to study much of the recent changes in the confirmation process.

These measures have the advantage of examining how judges actually turned out and not simply relying on "input" measures such as what law school the nominee went to. Presumably, the Senate and president are able to guess on average how well a nominee will do once he or she is on the bench and it is useful to see whether the best judges had particularly easier or more difficult times getting through the confirmation process.

The ABA ratings are on an 11-point scale that ranges from "not qualified" to "extremely well qualified." The different gradations include not qualified/qualified, qualified/not qualified, qualified, qualified/well qualified, and so on. The presidential approval ratings are from the Gallup

\footnotetext{
${ }^{16}$ Goldberg (2005) provides an interesting critique of using the Choi-Gulati indexes for evaluating appeals court judges for the Supreme Court in that the two different jobs do require different sets of skills. His critique is useful, but it does not apply to the data as they are being used here because I am just using them to evaluate how well the judge did on the appeals court and comparing that to how tough the confirmation process was for that job.
} 
survey. ${ }^{17}$ Information on the senators from each state at the time of nomination and their political affiliation was obtained from the Congressional Biographical Directory.

The Almanac of the Federal Judiciary provided detailed information on many of the nominees, such as where the judicial nominees clerked (state supreme court, federal district court, federal appeals court, or the U.S. Supreme Court). All clerkships are surely not the same, with the U.S. Supreme Court being the most difficult to obtain, followed by the federal appeals court and then the federal district court. Using the rate that judicial nominees had held clerkships as a measure of quality is somewhat problematic because the number of available clerkships has risen over time. One way of trying to account for this is to examine how the returns to having obtained different levels of clerkships vary across any given president's nominees. $^{18}$

An attempt was also made to use the Almanac's survey of lawyers who later had cases before the judge that evaluated whether the judge was "smart" or not, but all the judges seemed to be described as at least smart, and any finer categorization seemed arbitrary given the relatively imprecise statements made by the lawyers. However, it was surprising that all the judges were rated as at least being smart, and it provides some evidence that even the judges who made it through after receiving a "qualified/nonqualified" rating from the $\mathrm{ABA}$ were able to function intelligently on the bench.

The Almanac was more useful for obtaining information on judicial temperament and political views. The evaluations presented from lawyers provide fairly clear statements on whether a judge's temperament could be classified as bad, fair, or good. The classification of a judge as having a "bad" judicial temperament is illustrated by lawyers' comments on A. Raymond Randolph and Richard F. Suhrheinrich, two nominees by George H. W. Bush.

For example, several lawyers said of Arthur Raymond Randolph: "No one will ever accuse him of excessive tact"; "He can be difficult and nasty if he is against you in a case"; "His questions can be tinged with sarcasm"; "He can sometimes be a little surly"; "He appears to be a little sour from the

\footnotetext{
${ }^{17}$ Edwards and Gallup (1990) provided survey data up through 1988. Survey data after that date are provided from the subscriber portion of the Gallup website.

${ }^{18}$ Frank Easterbrook pointed this out to me.
} 
bench-not because he is displeased, or is going to vote against you-it is just the way he is."

About Richard F. Suhrheinrich, they said: "His judicial demeanor leaves something to be desired"; "His demeanor is a problem. He's not necessarily attorney friendly"; "His interpersonal behavior is abysmal"; "You need to wear armor when you have him on your panel"; "Some people say he's mean-spirited. I would say he has a harsh streak"; "He's a bully."

Examples of judges classified as fair have evaluations that contain phrases like: "He's gruff, but treats attorneys OK"; "He is generally courteous and cordial and sometimes testy and argumentative"; "His demeanor is all right"; "She can actually be quite hostile on oral argument." By contrast, those discussed as "good" were described as: "He has a fantastic temperament"; "He treats lawyers very well"; "There is no problem with his temperament."

As far as political views go, lawyers noted that judges were either liberal, moderate, conservative, libertarian, or neutral. Some judges were categorized differently on the political scale by different lawyers. When that was the case, those judges were simultaneously listed in multiple categories. The reason for distinguishing judges by political views rather than merely by who appointed them is that obviously not all nominees from even the same president have the same views.

Unfortunately, the Almanac's survey information is only provided with a several-year lag and thus covers very few of George W. Bush's nominees. Indeed, only seven circuit court nominees and 14 district court nominees have such survey information.

\section{A First Examination of the Data}

The following graphs clearly show how nominees in recent years have taken a dramatically longer time to be confirmed, and that the confirmation rate of circuit court nominees has fallen.

Figure 1 illustrates that over the last 26 years it has taken much longer to get nominees through the confirmation process for the judges. A rough look at this figure shows that the nomination process can possibly be broken down into three distinct periods. From the Carter Administration through the first six years of the Reagan Administration, the length of the confirmation process, for both district and circuit court nominees, fairly consistently remained around 50 days. However, during the last two years of 
Figure 1: Days between nomination and confirmation during Congress when judge was nominated.

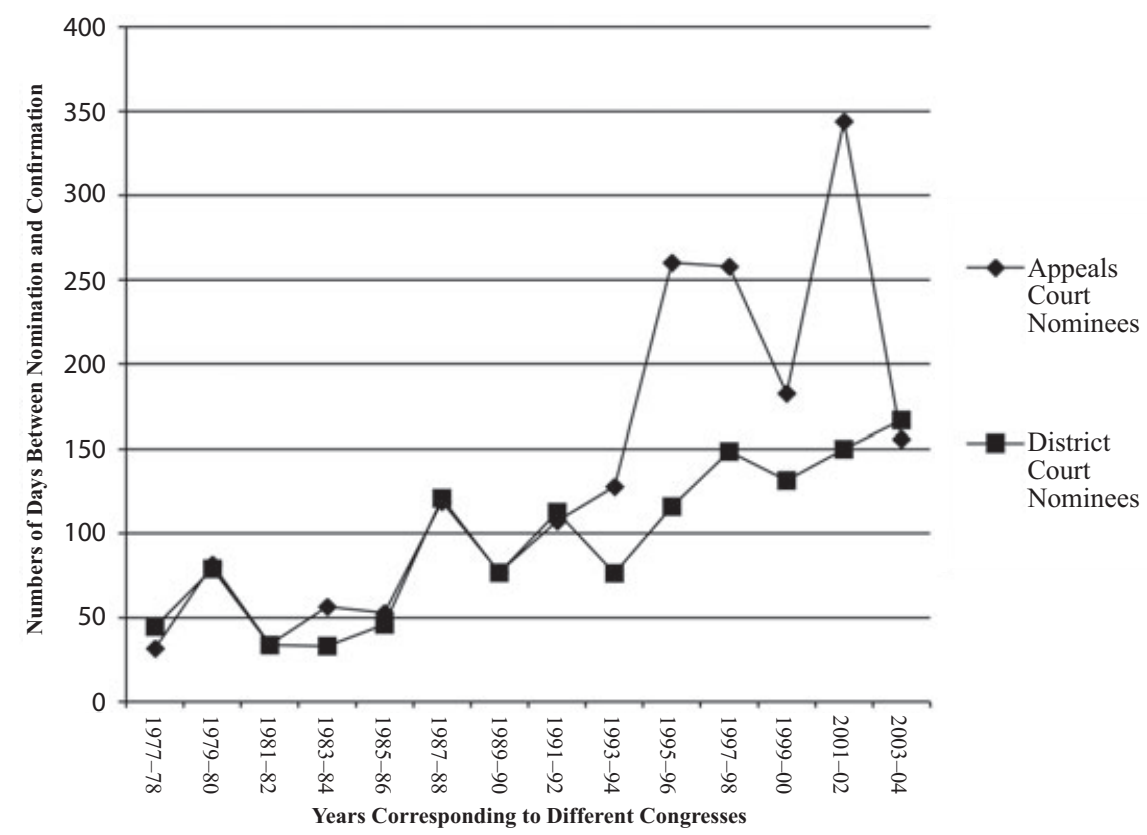

Source: Lower Federal Court Confirmation Database, the Office of Legal Policy in the Department of Justice, and a Lexis-Nexis search.

Reagan's second term, things changed. With the Democratic takeover of the Senate and the battle over Judge Robert Bork's nomination to the Supreme Court in 1987, it took 120 days for both district and circuit court nominees to get through. That new higher rate continued through 1993-1994. The final period appears to extend from when the Republicans took over the Congress in 1995 through the first Bush Administration, though the circuit court nominees during the first two years of the Bush Administration took a dramatically longer period of time (about 320 days (or 200 percent) longer than the was the case during the last two years of the Clinton Administration). It is only during this last period that circuit court nominees take much longer than those for the district court.

Since comparisons are naturally made by presidential administrations, Figure 2 breaks down the length of the nomination process by administration. The results largely illustrate what was already shown in Figure 1, but 
Figure 2: Days between a president's judicial nominations and confirmations during that president's time in office.

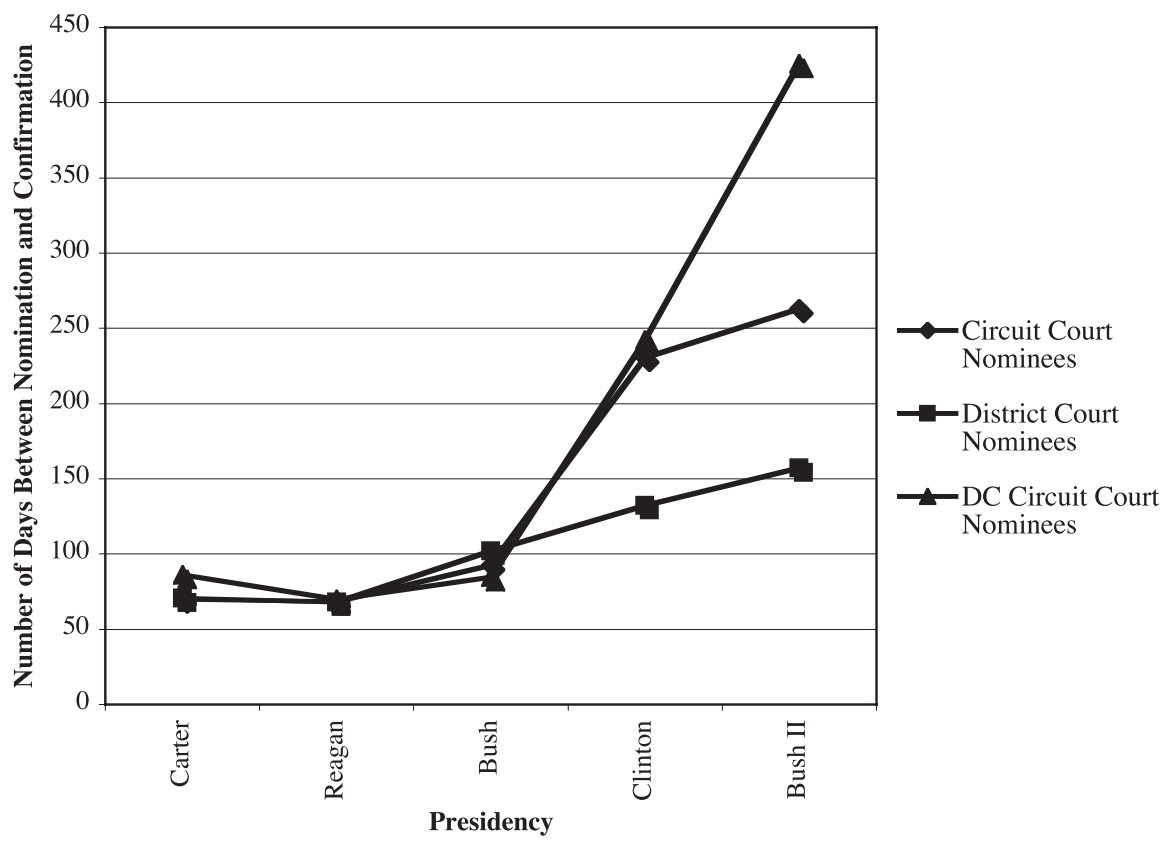

Source: Lower Federal Court Confirmation Database, the Office of Legal Policy in the Department of Justice, and a Lexis-Nexis search.

demonstrate the very consistent growth in the length of the confirmation process starting with the first Bush Administration and the explosion in the length of the confirmation process for circuit court nominees that started for Clinton and continued growing under Bush II. The gap between the district and circuit court nominees under the Clinton and Bush II Administrations is remarkable. These figures undoubtedly underestimate the impact of these delays because as the nomination process gets progressively more difficult, nominations that would previously have been made would no longer be made.

An even bigger change occurred in how long it takes to confirm nominees to the District of Columbia Circuit Court, which is the second most powerful federal court and considered a training ground for future Supreme Court Justices. During the Carter, Reagan, and Bush I Administrations, it 
Figure 3: Months between nomination and confirmation: district court judges.

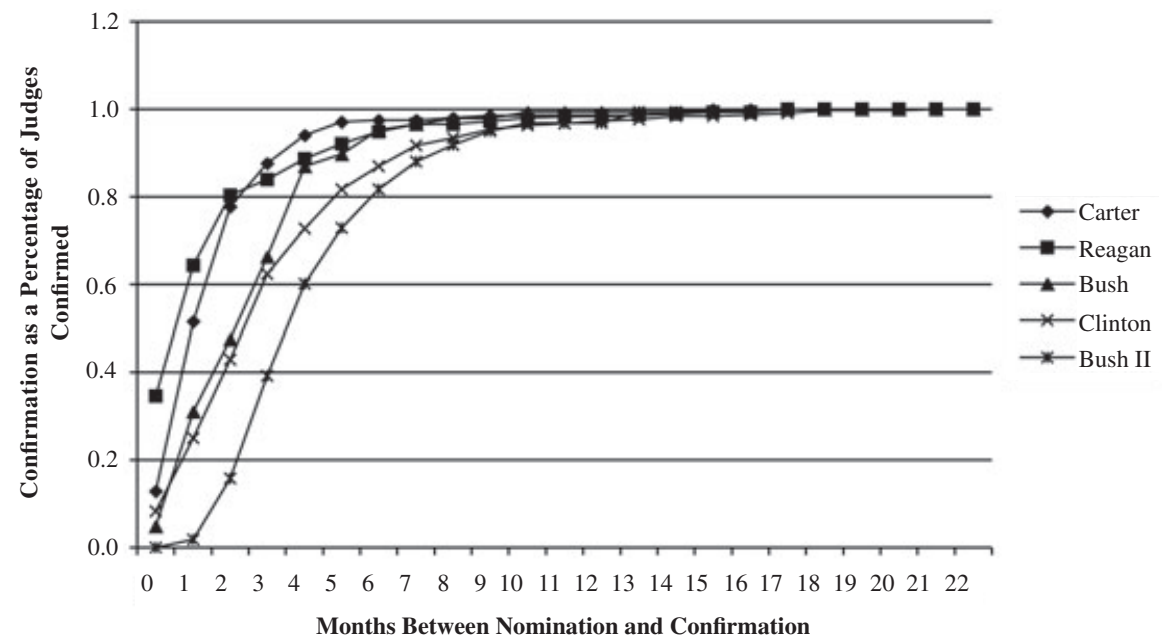

Source: Lower Federal Court Confirmation Database, the Office of Legal Policy in the Department of Justice, and a Lexis-Nexis search.

took fewer than 87 days from nomination to confirmation. Under Clinton, this grew to 242 days and 726 days under Bush II. ${ }^{19}$

I examined similar raw data on the length of confirmations for the Supreme Court starting with Hugo Black in 1937 and ending with Stephen Breyer in 1994. The longest confirmation period was for Steward Potter in 1959 at 108 days, followed by Clarence Thomas at 99; William Rehnquist at 89; and Antonin Scalia at 85. The Reagan and Bush I Administrations experienced the longest confirmation processes, with the Eisenhower Administration just slightly edging out the Clinton Administration for the third longest confirmation periods. Generally, the nominees in the three most recent administrations experienced longer confirmations.

Figures 3 and 4 show the cumulative distribution in how long it takes for nominees to be confirmed. Both figures show that very few nominees are quickly confirmed any more. For example, in Figure 3, almost 40 percent of

\footnotetext{
${ }^{19}$ There are not a large number of nominees to the District of Columbia Appeals Court in any administration. For the five administrations studied here, Carter had four nominees, Reagan had 16, Bush I had nine, Clinton had nine, and Bush II had six.
} 
Figure 4: Months between nomination and confirmation: circuit court judges.

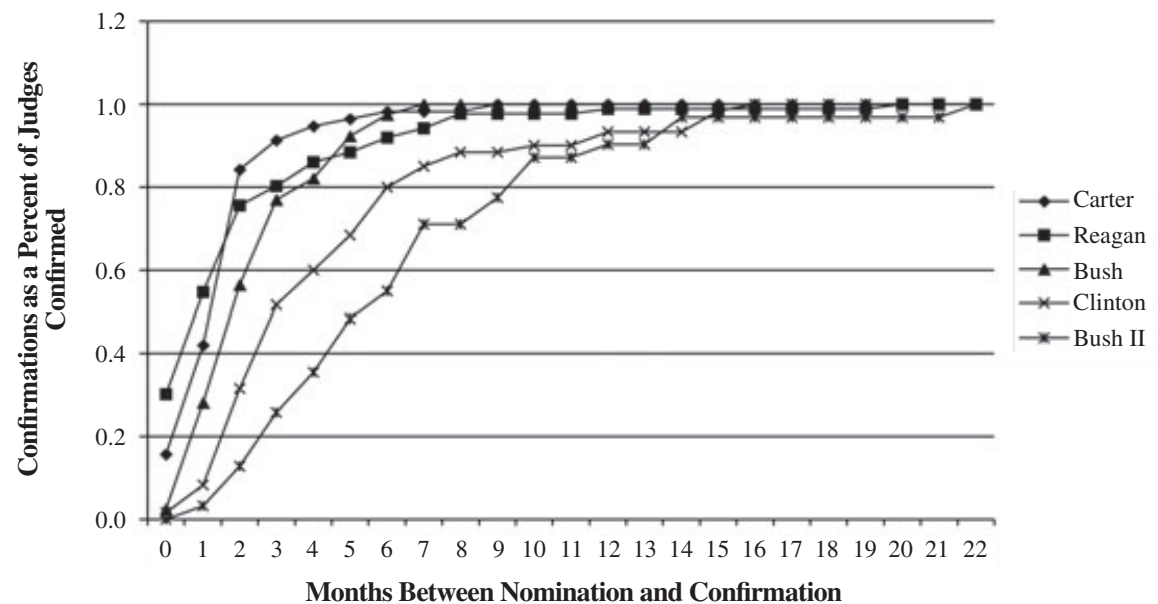

Source: Lower Federal Court Confirmation Database, the Office of Legal Policy in the Department of Justice, and a Lexis-Nexis search.

Reagan's district court nominees were confirmed within a single month. By contrast, it took almost three months for Bush II nominees to reach the same rate. The distributions of confirmation lengths were almost identical under both the Clinton and Bush I Administrations. For circuit court nominees in Figure 4, Reagan got the same percentage of judges confirmed within the first month that it took Bush II to achieve. The whole process of delay can be seen in these figures. Carter got over 80 percent of his nominees confirmed within two months, while Bush II took a year to obtain a similar percentage.

The changes in confirmation rate are not as dramatic as the changes in the length of time to confirmation. Indeed, the confirmation rate for district court nominees during the 2003-2004 term ended up at virtually the same rate that it started with in 1977-1978. What has changed is the confirmation rate for the circuit court. Although the appeals court confirmation rate for any Congress ranged from 92 to 100 percent from 1977 to 1986 and was again as high as 100 percent during the first two years of the Clinton Administration, the rate has not risen above 82 percent after that. Clinton suffered the lowest confirmation rate during his last two years in office, though overall Bush II had a 10 percentage point lower confirmation rate 
Figure 5: Percentage of each administration's nominees that was confirmed.

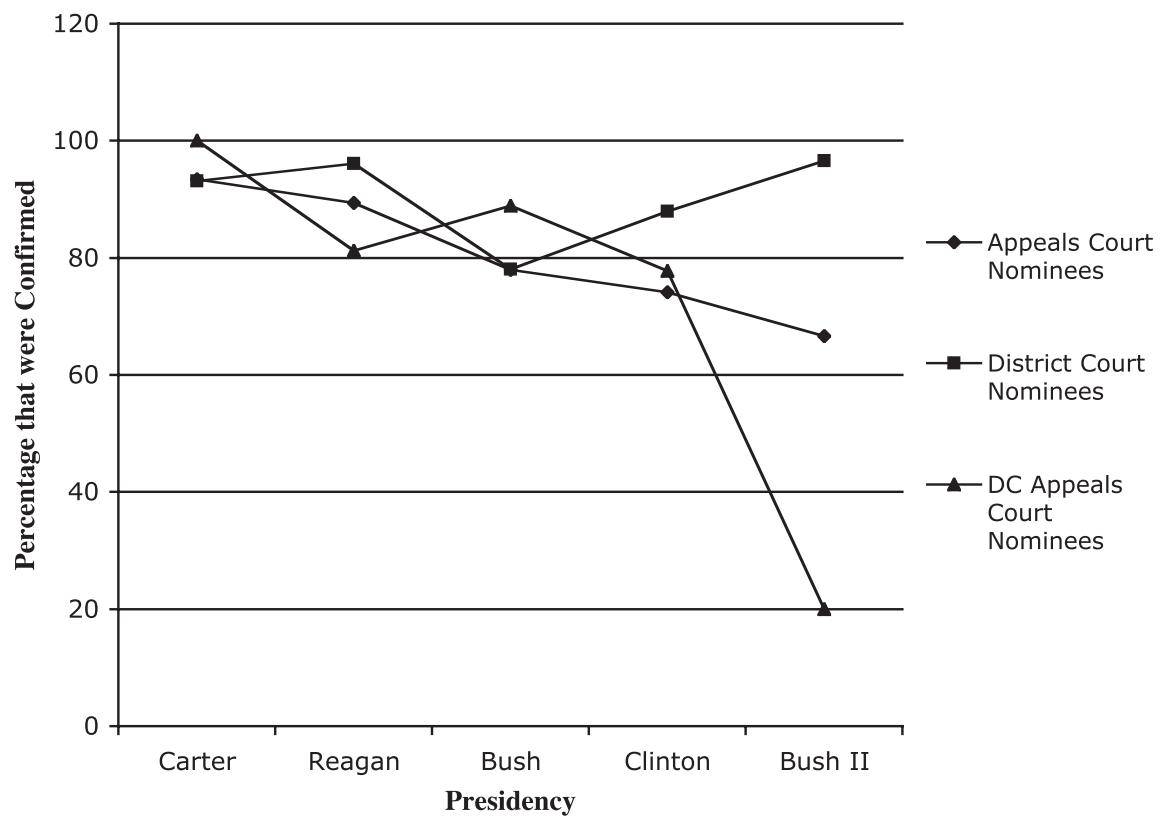

Source: Lower Federal Court Confirmation Database, the Office of Legal Policy in the Department of Justice, and a Lexis-Nexis search.

at 64 percent (see Figure 5). Figure 5 also shows that while Bush II faced lower circuit court confirmation rates, the District of Columbia Circuit Court is again singled out for special discrimination. During the Clinton Administration, while two out of nine District of Columbia Circuit Court nominees were defeated, four out of five were defeated under Bush II. Figure 5 looks at the numbers for the Supreme Court, and the only consistent pattern is that all but two of the presidents (Nixon and Reagan) experience 100 percent confirmation rates. ${ }^{20}$

A broader issue is whether these changes over time, particularly during Bush II, could be explained by changes in the quality of the nominees. Quality is measured by whether the nominee attended a top-10 law school,

\footnotetext{
${ }^{20}$ Lyndon Johnson had an interesting experience in that he had nominations for the Chief Justice and another position on the Court that were never consummated because the persons they were supposed to replace only left after Nixon became president.
} 
served as a judicial law clerk, and ABA ratings. In terms of either what law school the nominees attended or their ability to obtain clerkships, quality rose consistently from Bush I to Clinton to Bush II. ${ }^{21}$ Combining the top two ABA categories together (well qualified and well qualified/qualified), Bush II's circuit court nominees do not obtain as good ABA ratings (65 percent) as Carter (77 percent) or Clinton (72 percent), but much better than the ratings for Bush I (56 percent) or Reagan (52 percent). It is difficult to discern any pattern in these four figures that would offer much of an explanation for the lengthened confirmation process or the drop in the confirmation rate.

As mentioned before, a better measure of quality may be the actual productivity of judges after they have obtained their positions, though the two measures by Choi-Gulati and Landes-Lessig-Solimine (LLS) show different patterns of change over time. Figure 6 shows how the Choi-Gulati composite quality rating varies for the first four administrations studied here. The Choi-Gulati rating is based on the number of decisions produced by a circuit court judge, the cites to those decisions in circuits outside the judge's own circuit, and the judge's independence. ${ }^{22}$ This measure does not explain changes over time in either how long it takes for confirmation or the confirmation rate. Both Carter and Clinton nominees have very low ratings (with Carter having the lowest) while Reagan nominees have by far the highest ratings.

The LLS total influence indexes based on outside and inside circuit citations are illustrated in Figure 7. The inside circuit citations is similar to the Choi-Gulati rating in that judicial quality peaks with Reagan's nominees, but outside circuit citations show that judicial quality is declining over time across the three administrations shown.

These ex-post measures of quality are obviously not available to either the Senate or the president during the confirmation process, but it is rational to expect that they have some general idea about the quality of nominees and it is the one objective measure not of the inputs into being a good judge (education, etc.) but of the outputs (the quality of their decisions). Unlike the other ex-ante measures, the Choi-Gulati and LLS indexes imply

\footnotetext{
${ }^{21}$ Given that the top-10 law schools account for a smaller share of total lawyers over time, one would expect the share of nominees from those schools to decline.

${ }^{22}$ The data are from their Appendix H.
} 
Figure 6: Choi-Gulati composite quality rating (equal weighting of quality, productivity, and independence using opinions during the 1998-2000 period for active circuit court judges age 65 or less in 2003).

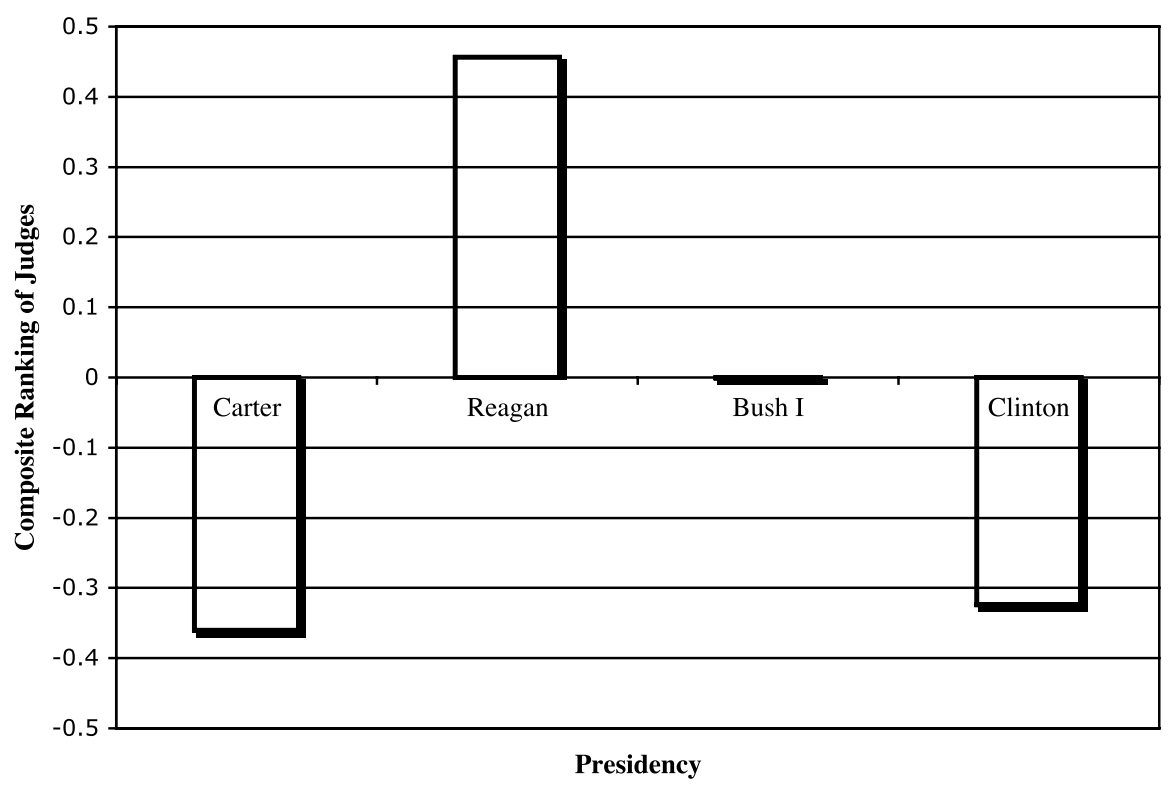

that the quality of judges has declined at least since the Reagan Administration. If correct, these measures raise concerns that the quality of judges has been falling while the confirmation process has become progressively more difficult.

Nominees' political views as measured by lawyers surveyed by the Almanac of the Federal Judiciary also do not explain the changes in confirmation rates or the length of time to confirmation. Although the sample is extremely small and contains information on only five of the 34 circuit court nominees who have been confirmed under Bush II, lawyers did not perceive Bush's circuit court nominees who were confirmed as conservative as Reagan's or Bush I's nominees and more lawyers perceived them as slightly more liberal. Nor did they perceive Clinton's nominees as being as liberal as Carter's.

Finally, the data allow a rough look at the claim that "delays in approving Clinton's minority and female judges showed racist and sexist 
Figure 7: Landes, Lessig, Solimine indexes for total influence (circuit court judges who were on the bench by January 1, 1992 and who had served at least six years by 1995).

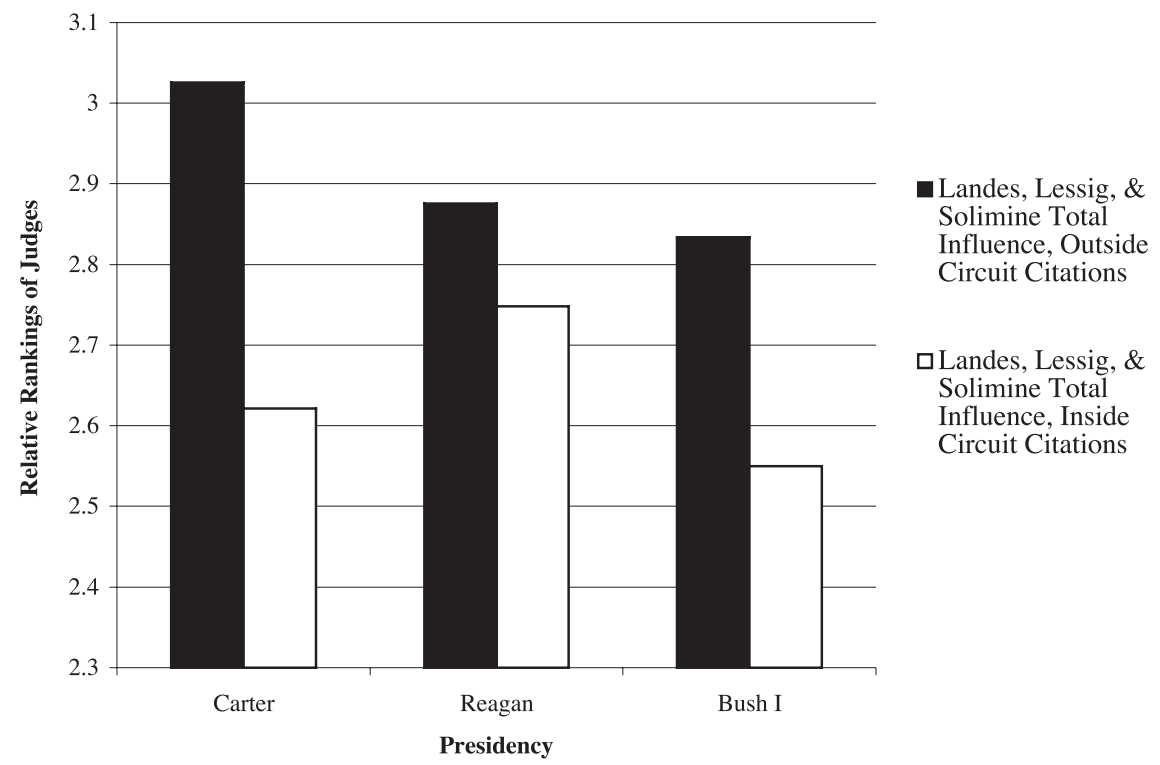

tendencies in the Senate" (Holland 2000b; Ross 2000). Since those claims were based on aggregating district and circuit court judges together, I have done that here simply for comparison, and doing this shows that there is indeed an increase in the length of confirmations for African Americans, Hispanics, and women. Yet Bush's African-American and female nominees are taking even longer to confirm than Clinton's did-245 days on average versus 141 and 230 versus 172, respectively. Clinton's Hispanic nominees took much more time than Bush's (234 days vs. 191), but it is not correct to argue that there was systematic discrimination against minorities as a whole.

This rough initial examination of the data indicates that it has taken much longer to get judges confirmed, but there has also been a sharp drop in confirmation rates for circuit court judges. The graphs clearly show how important it is to separately examine district and circuit court judges. Combining the two groups would clearly hide the changes that are occurring within the more important positions. 


\section{A More Systematic Examination}

\section{A. The Length of Confirmation Process}

Obviously, many factors affect both the length of time to confirmation as well as whether a nominee will even be confirmed. Probably the most important effect is simply whether the Senate and president are of the same party. The speed at which hearings are held, the rules under which they are considered (e.g., whether it takes both home state senators to block a nomination using so-called blue slips), and even the likelihood that the nominee can muster a majority in committee or on the floor are all affected by whether the same party controls the presidency and the Senate. Since the senators from the judge's home state have a disproportionate influence on confirmation through the use of blue slips, controls are also used for the different possible party affiliation combinations of home state senators and the president. Over time, the rules have varied on whether it requires either both or one home state senator to block a vote on a nominee. ${ }^{23}$

The year of a president's term also seems to be important as election years (particularly the year of the presidential election) may greatly lower the rate at which the Senate votes on nominations. As noted in the Introduction, many believe that the race or gender of nominees affect how their cases are handled before the Senate. Other factors include the quality of judges (as measured by where they went to law school or clerked or their ABA rating), whether the nominee already has a record as a state or federal judge, whether the nominee engaged in private practice or worked in the government, the number of nominations in a year, and whether a nominee is renominated by a different president.

Table 1 examines the number of days between nomination and confirmation. Negative binomial regressions are used because of the count nature of the data and since the mean and variance of the days-toconfirmation variable are not equal. Three regressions are reported for both district and circuit court judges: dummy variables for the administration that first nominated different judges and a dummy variable for whether the same party controls both the presidency and the Senate, that specification with

\footnotetext{
${ }^{23}$ When Senator Orrin Hatch ran the judiciary committee during the Clinton Administration, a vote would not occur "if either home-state senator objected to a nomination to the federal bench." This rule continued during George W. Bush's first term when the Democrats controlled the Senate. When the Republicans took over under Bush II, the rule was changed to only block votes when both of a home state's senators objected (Curry 2004).
} 


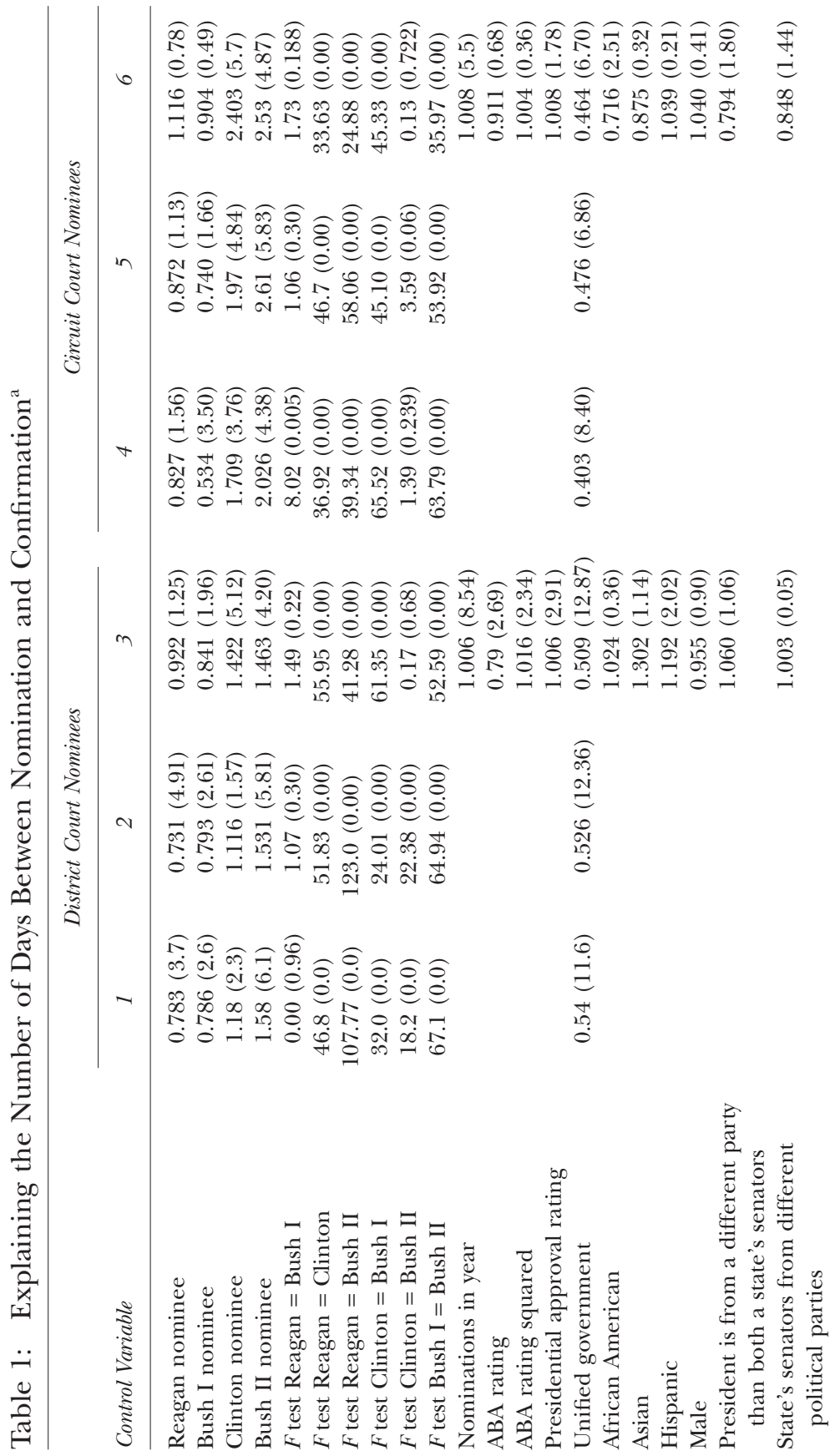




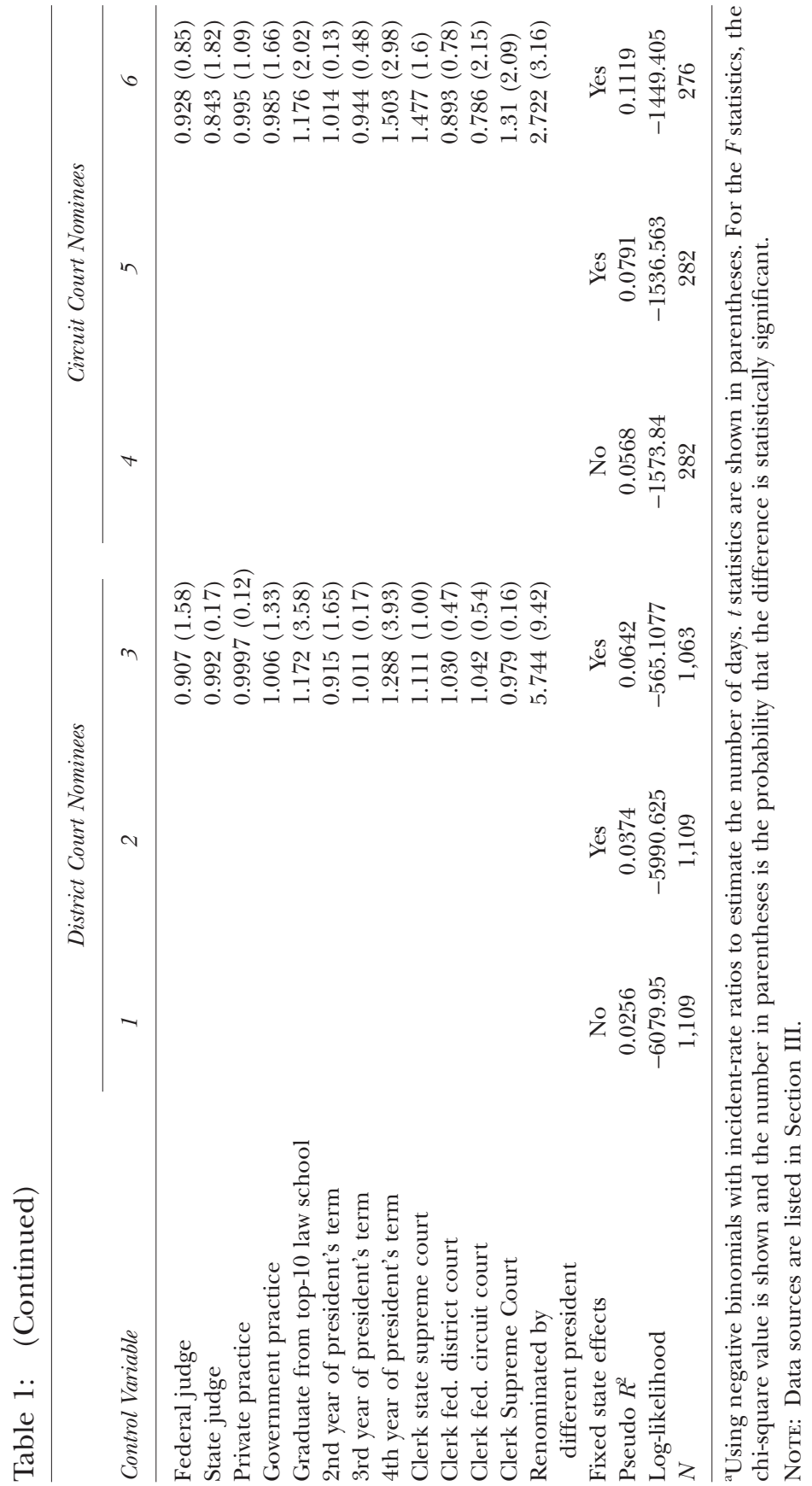


state fixed effects, and finally those variables plus the other factors mentioned above. The coefficients are incident-rate ratios and show the percent change in the number of days for a one-unit change in the exogenous variable. (Cox, exponential, and Weibull survival time maximum-likelihood models were examined, and the pattern of results were very similar to what is shown in Table 1.)

The patterns for district and circuit court judges are very similar. The simplest regressions show that after the Carter Administration, the length of time to confirmation initially got shorter under Reagan and Bush I by some 20 percent for district court judges and between 13 and 47 percent shorter for circuit court judges. All the estimates imply that the Clinton Administration district court judges took at least 12 percent longer and circuit court judges at least 71 percent longer to be confirmed. Bush II's district court nominees took at least 53 percent longer and circuit court nominees at least 103 percent longer. The results thus confirm the previous graphs and show that even after other factors are taken into account, the confirmation process takes much longer and that this process has gotten particularly long for circuit court judges, with Bush II's circuit court nominees taking between 2.8 and 3.8 times longer to be confirmed than under his father. With the general exceptions of the differences between Reagan, Carter, and Bush I, the differences between those first three administrations and either the Clinton or the Bush II Administrations were very statistically significant.

Not surprisingly, having the same party in control of both the presidency and the Senate makes a large difference in how long confirmation takes and the effect is somewhat larger for the more contentious process involving circuit court nominees. Having a unified government reduces the length of the confirmation process for district court nominees by 46 to 48 percent and for circuit court nominees by 52 to 60 percent.

Some other variables also provide consistent effects for both district and circuit court nominees. Also as expected, more nominees in a year slows down the speed with which any nominee will be confirmed, with each additional nominee increasing the number of days by about 1 percent. Higher ABA ratings speed up the confirmation process, though at a decreasing rate. Having been either a federal or a state judge prior to nomination also speeds up the process by about 1 to 16 percent. Nominations made during the fourth year of a president's term increase the length of district court nominations by 29 percent and those for the circuit court by 48 percent.

Rerunning these regressions for either the number of days between the initial nomination and the hearing date or between the hearing date 
and the confirmation date produce similar results, though there is a noticeably longer delay for circuit court nominees after the hearing. For the circuit court, from the Carter to the Bush II Administrations, there is a 272 percent increase in the number of days between nomination and hearings but a 404 percent increase from hearings to confirmation. Just between the Clinton and Bush II Administrations there is a doubling of the number of days between hearings and confirmation for circuit court nominees. This evidence also helps answer the question of whether the increasing delays might simply arise because judges' records have become more complex over time and thus take a longer time to examine. Presumably, more complex records would require more time to review before hearing, not after the hearings have been completed. Yet, that is not consistent with the evidence.

There are, however, some differences between district and circuit court nominees, especially with respect to race, gender, and clerkships. For example, while African Americans take just as long as whites to be confirmed to district courts, they are confirmed 28 percent faster to circuit courts. For males, the results are not statistically significant but do suggest that males are confirmed faster than females for district courts but take longer for circuit courts. Having clerked for the Supreme Court hurts nominees for the circuit courts but has no effect on nominees for the district courts.

Interestingly, for both types of judicial appointments, a higher presidential approval rating at the time of the nomination results in longer confirmations. Possibly, presidents with higher approval ratings push to nominate judges that are more difficult to confirm and they might feel that they can take gambles they would not risk if their popularity were lower. A test of this is whether Republican presidents tend to nominate more conservative nominees as their approval ratings rise and whether Democratic presidents tend to nominate more liberal ones. ${ }^{24}$ The results imply that increasing a Republican president's popularity by one percentage point increases the probability of a conservative being nominated by 1 percent and lowers the probability of a liberal being nominated by 6 percent (though the relationship with conservative nominees is not statistically significant). Similarly, for a Democratic president, increasing his popularity by one percent-

\footnotetext{
${ }^{24}$ These variables are not included in the general regressions shown in Table 1 because so few of Bush II's nominees are covered by the Almanac's survey. Doing so does not produce any statistically significant results at the 10 percent level for a two-tailed $t$ test for whether a nominee was perceived of as liberal, conservative, moderate, or libertarian.
} 
age point reduces the probability of a conservative being nominated by 3 percent and increases the probability of a liberal being nominated by 3 percent.

Figure 2 suggested that nominees to the District of Columbia Circuit Court, the second most important court, were treated differently than those for other courts during Bush II's administration. Although there are few nominations to this court in any administration, we can still account for whether the same party controls both the presidency and the Senate and test whether the differences are statistically significant. The results in Table 2 suggest that having the same party control both the presidency and the Senate has a much bigger impact on confirmation speed than it does for all other district or circuit courts. This result is consistent with there being more at stake for nominations to this court. The estimates imply no consistent pattern over time for the length of confirmation for District of Columbia District Court nominees, but the District of Columbia Circuit Court numbers imply a "V" shaped relationship, with the length of confirmations falling from Carter to Bush I and then rising dramatically after that. The small sample means that many of the results are not statistically significant, though the fall from Carter to Bush I and the subsequent rise through Bush II are significant at least at the 1 percent level.

The first six specifications in Table 3 use the specifications in Column 6, Table 1 to examine the relationship between the Choi-Gulati composite index as well as the five Landes et al. (LLS) indexes and whether the most successful circuit court judges in terms of quantity and quality of productivity had a greater difficulty in getting confirmed. The Choi-Gulati composite index, ranging from -2.44 to 3.77 with more positive ratings implying higher quality, has a standard deviation of almost 1 (equaling 1.003). ${ }^{25}$ The incident-rate ratio implies that increasing the Choi-Gulati composite index by one standard deviation produces a 93 percent increase in the length of the confirmation process.

The five LLS indexes also imply that the most successful judges faced the most difficult confirmation battles, though the relationship is smaller and less statistically significant than was true for the Choi-Gulati index. Three

\footnotetext{
${ }^{25}$ I regressed the Choi-Gulati index on the Almanac's survey of judges' political beliefs and circuit court fixed effects and found no statistically significant relationship between political views and this measure of judicial quality. The only measure that came close to being statistically significant was whether the judge was libertarian and the coefficient was negative $(-2.1$, $t$ statistic $=-1.50)$.
} 
Table 2: Explaining the Number of Days Between Nomination and Confirmation for the District of Columbia Circuit ${ }^{\mathrm{a}}$

\begin{tabular}{|c|c|c|c|}
\hline Control Variable & $\begin{array}{c}\text { DC District Court } \\
\text { Nominees } \\
1\end{array}$ & $\begin{array}{c}\text { DC Circuit Court } \\
\text { Nominees } \\
2\end{array}$ & $\begin{array}{l}\text { DC Circuit and Federal } \\
\text { Court Circuit Nominees } \\
3\end{array}$ \\
\hline Reagan nominee & $\begin{array}{c}2.246 \\
(1.88)\end{array}$ & $\begin{array}{c}0.563 \\
(1.67)\end{array}$ & $\begin{array}{c}0.709 \\
(1.24)\end{array}$ \\
\hline Bush I nominee & $\begin{array}{r}0.581 \\
(0.60)\end{array}$ & $\begin{array}{r}0.327 \\
(2.40)\end{array}$ & $\begin{array}{r}0.387 \\
(2.16)\end{array}$ \\
\hline Clinton nominee & $\begin{array}{r}1.417 \\
(0.79)\end{array}$ & $\begin{array}{l}1.288 \\
(0.62)\end{array}$ & $\begin{array}{r}0.971 \\
(0.09)\end{array}$ \\
\hline Bush II nominee & $\begin{array}{r}0.985 \\
(0.02)\end{array}$ & $\begin{array}{l}1.645 \\
(0.85)\end{array}$ & $\begin{array}{l}3.828 \\
(2.28)\end{array}$ \\
\hline $\begin{array}{l}\text { Same party controls } \\
\text { presidency and senate }\end{array}$ & $\begin{array}{c}0.398 \\
(2.14)\end{array}$ & $\begin{array}{c}0.333 \\
(3.73)\end{array}$ & $\begin{array}{c}0.453 \\
(2.32)\end{array}$ \\
\hline$F$ test Reagan $=$ Bush $\mathrm{I}$ & $\begin{array}{l}2.37 \\
(0.124)\end{array}$ & $\begin{array}{l}2.41 \\
(0.121)\end{array}$ & $\begin{array}{l}2.91 \\
(0.088)\end{array}$ \\
\hline$F$ test Reagan $=$ Clinton & $\begin{array}{l}1.24 \\
(0.266)\end{array}$ & $\begin{array}{l}7.85 \\
(0.005)\end{array}$ & $\begin{array}{l}1.12 \\
(0.291)\end{array}$ \\
\hline$F$ test Reagan $=$ Bush II & $\begin{array}{l}1.87 \\
(0.171)\end{array}$ & $\begin{array}{l}4.65 \\
(0.031)\end{array}$ & $\begin{array}{l}10.15 \\
(0.0014)\end{array}$ \\
\hline$F$ test Clinton $=$ Bush $\mathrm{I}$ & $\begin{array}{l}1.21 \\
(0.271)\end{array}$ & $\begin{array}{l}17.68 \\
(0.000)\end{array}$ & $\begin{array}{l}4.74 \\
(0.030)\end{array}$ \\
\hline$F$ test Clinton $=$ Bush II & $\begin{array}{l}0.54 \\
(0.464)\end{array}$ & $\begin{array}{l}0.26 \\
(0.0004)\end{array}$ & $\begin{array}{l}5.64 \\
(0.0175)\end{array}$ \\
\hline$F$ test Bush I $=$ Bush II & $\begin{array}{l}0.41 \\
(0.522)\end{array}$ & $\begin{array}{l}12.33 \\
(0.0004)\end{array}$ & $\begin{array}{l}24.96 \\
(0.000)\end{array}$ \\
\hline Pseudo $R^{2}$ & 0.0320 & 0.0854 & 0.1138 \\
\hline Log-likelihood & -143.74 & -182.592 & -114.698 \\
\hline$N$ & 26 & 34 & 23 \\
\hline
\end{tabular}

${ }^{a}$ Using negative binomials with incident-rate ratios to estimate the number of days. $t$ statistics are shown in parentheses.

Note: Data sources are listed in Section III. Among the major data sources are: Lower Federal Court Confirmation Database, the Office of Legal Policy in the Department of Justice, and a Lexis-Nexis search.

indexes are significant at least at the 10 percent level for a two-tailed $t$ test and two others are not (being significant merely at least at the 24 percent level for a two-tailed $t$ test). A one standard deviation increase in these five quality indexes increases the length of the confirmation process by at least 30 percent. The most puzzling result is that while increasing total influence in terms of either the outside or inside circuit citations increases the length of the confirmation process, combining outside and inside circuit citations together is not significantly related. The results also imply that citations 


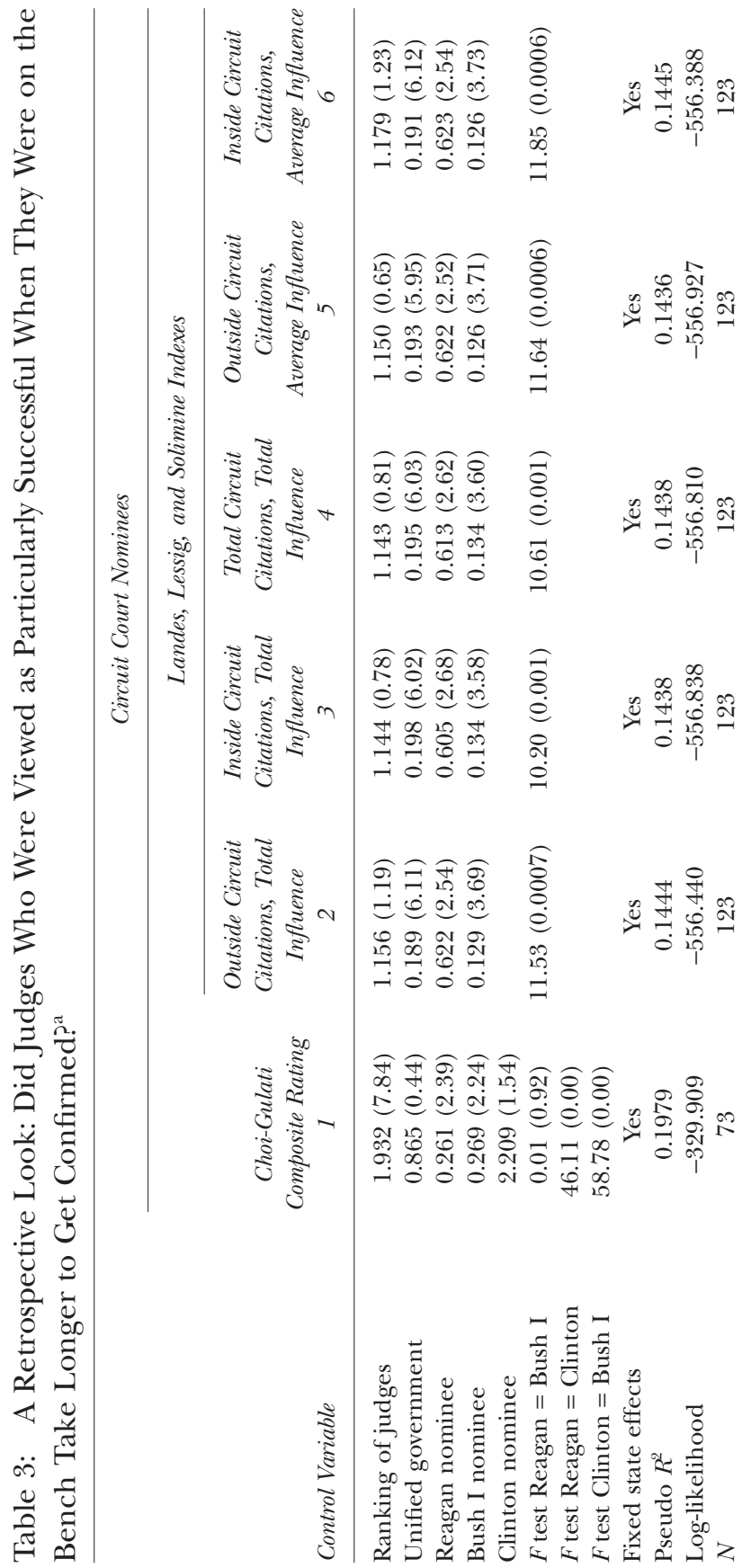




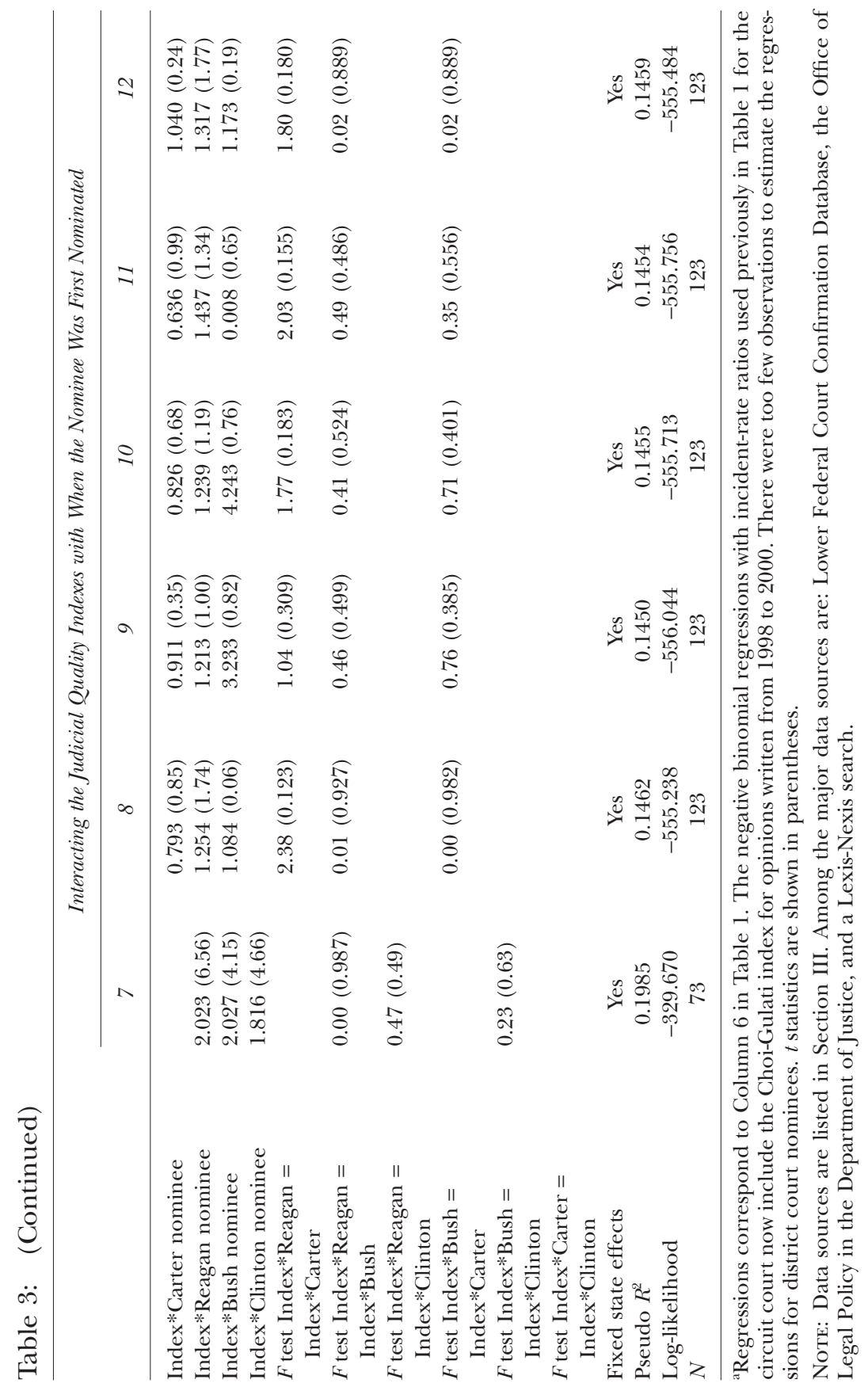


within a circuit are relatively more important in determining opposition to confirmation, and that the implied impacts between total influence and the average per opinion are small.

Judges Frank Easterbrook and Richard Posner are such extreme outliers in terms of their performance in these indexes that there is a question about how sensitive the results are to their inclusion in the sample. For example, in terms of the Choi-Gulati index, Posner's (3.77) and Easterbrooks's (2.93) ratings are almost a standard deviation and a half greater than the rating for the third judge (J. Harvie Wilkinson (1.51)). Yet, rerunning the regressions made very little difference in the estimates.

It is possible that both low- and high-quality nominees have difficulty being confirmed and thus that the relationship is not linear. To test this, I added in a squared value for each index shown in Table 3. For the ChoiGulati index this did not alter the results and the coefficient on the squared term was statistically insignificant and empirically very small: the linear terms are between one and four percentage points larger than those shown in the table (18 percent, 36.5 percent, and 97.6 percent, respectively), while the coefficient on the squared terms equals only two to three percentage points. ${ }^{26}$ The coefficient estimates were less consistent for the LLS indexes, but still generally implied that higher-quality appointments increase the length of the confirmation process, ${ }^{27}$ though only the coefficients measuring the total influence using outside circuit citations are statistically significant at least at the 5 percent level. There was one exception to this pattern. The total influence of inside circuit citations actually has a "J" shape with respect to the length of confirmations, where it initially declines and then rises. The impact of average influence of opinions in terms of outside circuit citations also increases confirmation lengths but implies an exception to the

\footnotetext{
${ }^{26}$ For the specification corresponding to Column 1 in Table 3, the coefficient on the Choi-Gulati composite ranking for judges increased slightly to $1.98(z$ statistic $=7.65)$ and the squared term is $0.971(z$ statistic $=-0.78)$. I also tried seeing whether the coefficient values were different for values of the Choi-Gulati index above and below zero, but in none of the cases was the $F$ test close to statistical significance.
}

\footnotetext{
${ }^{27}$ For the specification corresponding to Columns 2 through 6 in Table 3, the coefficient on the LLS rankings for judges was $2.83(z$ statistic $=1.99)$ and the squared term is 0.84 $(z$ statistic $=-1.75) ; 0.78(z$ statistic $=-0.35)$ and the squared term is $1.10(z$ statistic $=0.48)$; $1.21(z$ statistic $=0.12)$ and the squared term is $0.992(z$ statistic $=-0.04) ; 1.36(z$ statistic $=1.42)$ and the squared term is $0.49(z$ statistic $=-2.33)$; and $1.08(z$ statistic $=0.25)$ and the squared term is 0.964 ( $z$ statistic $=-0.31)$.
} 
other results in that highest-quality judges actually see a decline in how long their confirmations take.

By most measures, the higher the quality of the judge, the more difficult is the confirmation process. To put it differently, evaluating the linear estimates in Table 3 at the mean judicial quality implies that a 1 percent increase in judicial quality increases the length of the confirmation process by between 1 and 3 percent.

The top half of Table 3 shows that circuit court judges who were ranked more highly tended to take much longer to get confirmed, but there is the question of whether that was true across all administrations. To look at this, the last three estimates show how higher-quality nominees fare in the Carter through Clinton Administrations. All the coefficients indicate that higherquality nominees faced more difficult confirmation fights in all the administrations and the effects are statistically significant two-thirds of the time. When fixed geographic effects are included, higher-quality judges under Reagan, Bush, and Clinton all faced significantly longer confirmations and across all the results it is hard to see any partisan differences in how Republican and Democratic judges are treated. The last estimate that accounts for all the factors that might affect the length of the confirmation process indicates that higher-quality Reagan and Bush judges suffered significantly longer confirmations than Clinton nominees in getting confirmed. For the LLS indexes, there seems to have been a significant change in the confirmation process after the Carter Administration. Nine of the 10 coefficients interacting the LLS indexes with the Reagan and Bush I Administrations imply that the most productive judges had the most difficult confirmation processes.

Choi and Gulati provide 11 different indexes on their way toward creating their composite index. Table 4 examines how each of these 11 indexes is related to the length of the confirmation process. Ten of the indexes imply that higher (more desirable) scores result in longer confirmation processes (number of published opinions, total outside circuit citations, self-citations (a proxy for self-written opinions), outside circuit citations to judge's top 20 opinions, Supreme Court citations, average outside circuit citations per majority opinions, total invocations (a measure of how important the decision was when the judge's name is mentioned), average invocations per opinion, percent of invocations attributable to majority opinion, and judicial independence), though only two of these are statistically significant (total invocations and judicial independence). The one anomaly involves citations in law reviews where more citations (higher quality) are associated 


\begin{tabular}{|c|c|c|c|}
\hline 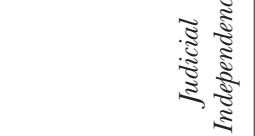 & $\approx$ & 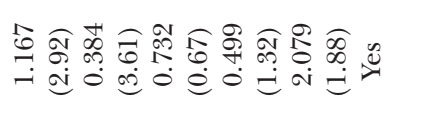 & $\begin{array}{ll}0 & \infty \\
10 & 10 \\
0 & \infty \\
0 & 0 \\
0 & 10 \\
0 & 10\end{array}$ \\
\hline 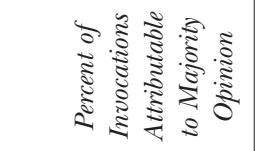 & $\stackrel{2}{2}$ & 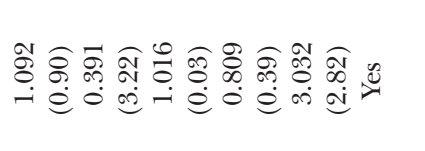 & 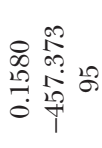 \\
\hline 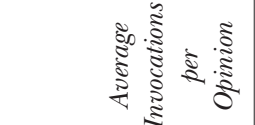 & $a$ & 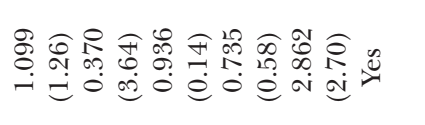 & 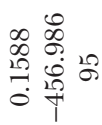 \\
\hline 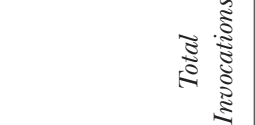 & $\infty$ & 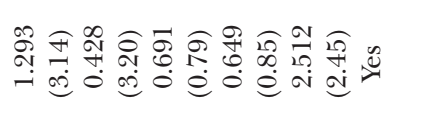 & 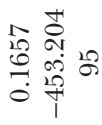 \\
\hline 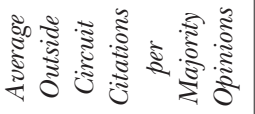 & $\wedge$ & 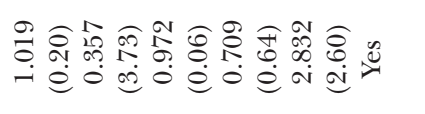 & 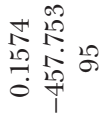 \\
\hline 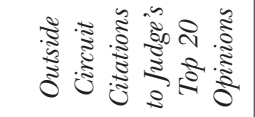 & 6 & 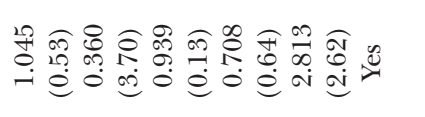 & $\begin{array}{ll}0 & 0 \\
1 & 0 \\
10 & 0 \\
0 & 0 \\
0 & 10 \\
0 & 10\end{array}$ \\
\hline 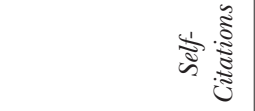 & in & 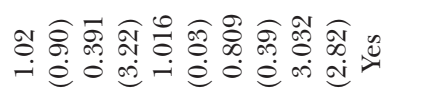 & $\begin{array}{ll}0 \\
0 \\
0 \\
0 \\
0 \\
0\end{array}$ \\
\hline 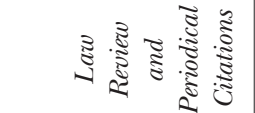 & $\nabla$ & 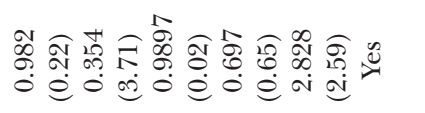 & 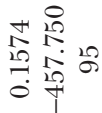 \\
\hline 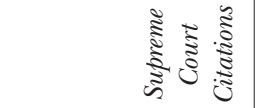 & $m$ & 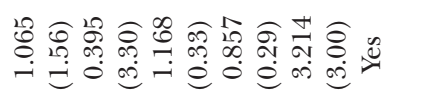 & 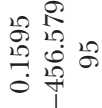 \\
\hline 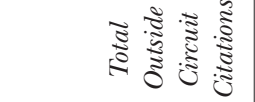 & $\sim$ & 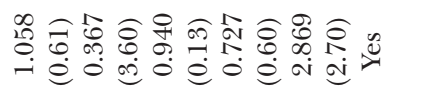 & 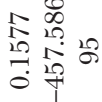 \\
\hline 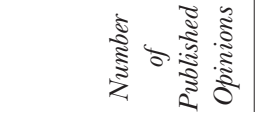 & -7 & 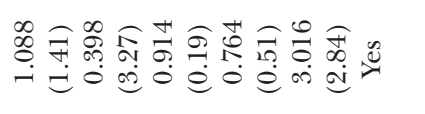 & 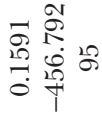 \\
\hline & 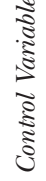 & 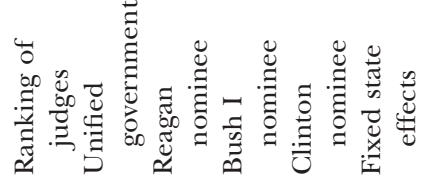 & 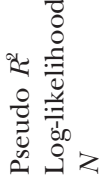 \\
\hline
\end{tabular}




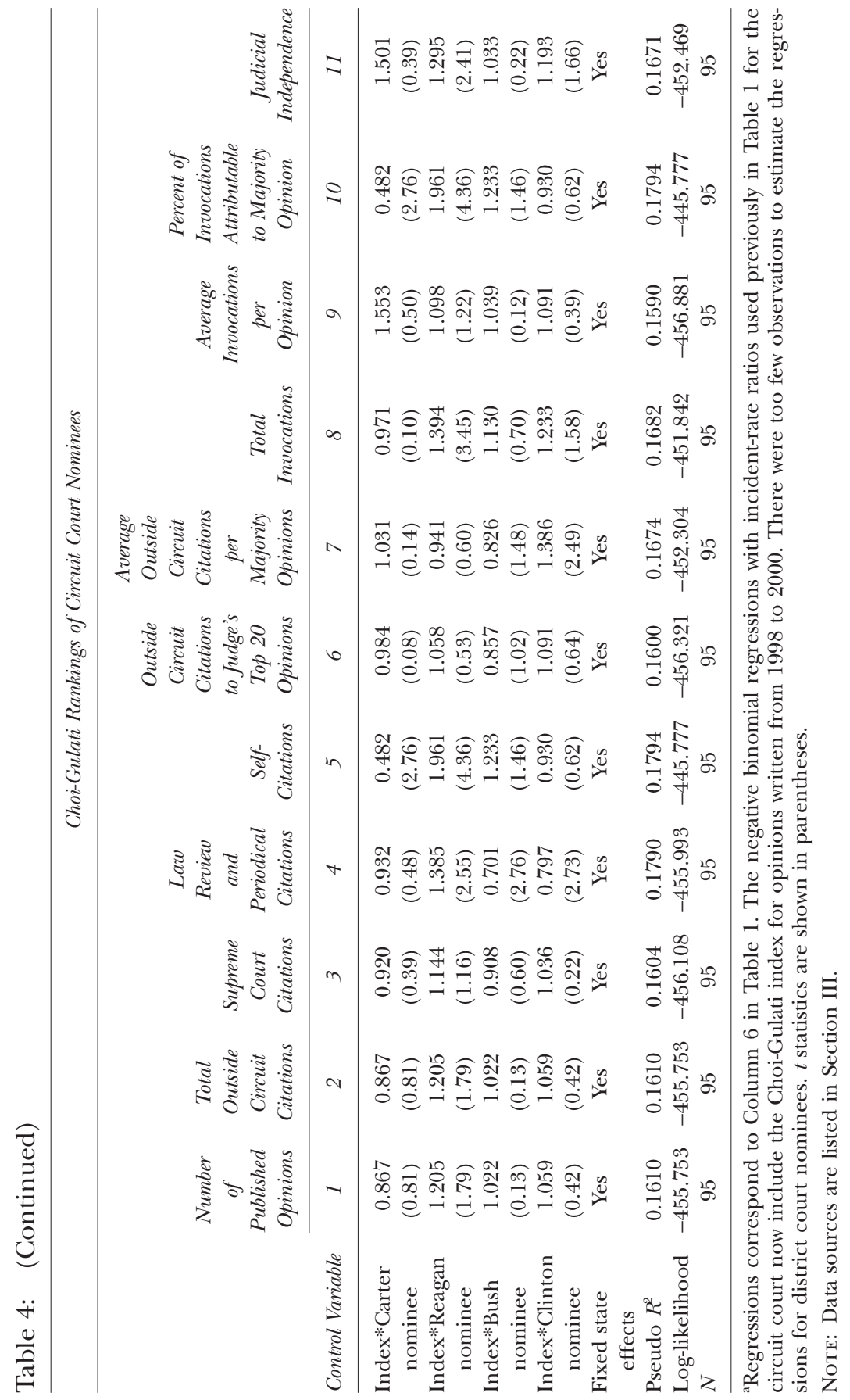


with shorter confirmation times, but even in this case it is quite statistically insignificant with a $t$ statistic of only 0.22 .

As before, it is possible to examine whether these indexes have different effects across different administrations. The bottom half of Table 4 reports these interactions and indicates that higher-quality judicial nominees were most likely to face greater delays for 10 of the 11 quality measures. President Clinton's nominees ranked second in this dimension, facing longer delays for 8 of the 11 quality measures.

I also examined whether the Choi-Gulati composite index varies systematically with other factors. Accounting for the same factors as accounted for earlier in Table 1 shows that only two things are consistently related to the index: the length of the confirmation process and being renominated by the next president. Again, higher-quality judges seem to be caught up in longer confirmation fights. It also appears as if the judges who are renominated tend to be much lower-quality judges. Indeed, the impact is so large that being renominated implies that a judge who would otherwise be ranked in the top 5 percent would actually be among the bottom 5 percent.

Looking at the differences between the ex-ante and ex-post measures of judicial quality finds little relationship between the two. Using the six expost measures of judicial quality from Choi-Gulati and LLS shown in Table 3 , variables for whether the nominee attended a top-10 law school, was on the law review, served as a judicial clerk for a state supreme court, federal district or circuit court, or U.S. Supreme Court, served as a federal or state judge prior to being on the circuit court, or the American Bar Association ratings together explain no more than 11 percent of the variation in judicial quality on the bench. Only two variables have a consistent positive impact on these judicial quality ratings (whether the nominee attended a top-10 law school and whether he or she served as a judicial clerk for the U.S. Supreme Court), though even in these two cases they are usually not statistically significant. Overall, of the 54 coefficients reported, only three show a significant positive relationship at least at the 10 percent level for a two-tailed $t$ test between ex-ante and ex-post quality and four show a similarly significant negative relationship. The ABA ratings are particularly weakly related to judicial quality, with none of the coefficients being even close to statistical significance and four of the six coefficients implying that higher ABA scores are associated with a lower-quality judge.

Does the Senate treat Republican and Democratic circuit court nominees differently? Table 5 takes Specification 6 in Table 1 and breaks down each variable into two: one interacted with a dummy for whether the 
Table 5: Examining Differences in Explanatory Variables for the Length of the Confirmation Process by Party ${ }^{\mathrm{a}}$

\begin{tabular}{|c|c|c|c|}
\hline \multirow[b]{2}{*}{ Control Variable } & \multicolumn{3}{|c|}{ Circuit Court Nominees } \\
\hline & Republican & Democrat & $\begin{array}{l}\text { F Test for Whether } \\
\text { Difference is Statistically } \\
\text { Significance (Probability) }\end{array}$ \\
\hline$A B A$ rating & $\begin{array}{l}\text { Dropped due } \\
\text { to collinearity }\end{array}$ & $\begin{array}{l}\text { Dropped due } \\
\text { to collinearity }\end{array}$ & \\
\hline Presidential approval rating & 1.0029 & 1.0003 & $0.16(0.6893)$ \\
\hline Unified government & 0.3741 & 0.4267 & $0.39(0.5321)$ \\
\hline African American & 0.3973 & 0.3265 & $0.16(0.6880)$ \\
\hline White & 0.7284 & 0.4735 & \\
\hline Asian & & 0.4759 & \\
\hline Male & 1.0663 & 0.7175 & $3.00(0.0833)$ \\
\hline Federal judge & 0.6534 & 1.0129 & $5.10(0.0239)$ \\
\hline State judge & 0.7224 & 1.1693 & $5.62(0.0178)$ \\
\hline Private practice & 1.0001 & 1.0150 & $0.84(0.3584)$ \\
\hline Government practice & 1.0062 & 0.9807 & $0.81(0.3693)$ \\
\hline Clerk state supreme court & 1.9772 & 1.6937 & $0.08(0.7785)$ \\
\hline Clerk fed. district court & 0.6080 & 1.4329 & $6.47(0.0110)$ \\
\hline Clerk fed. circuit court & 1.1451 & 0.8815 & $0.95(0.3288)$ \\
\hline Clerk Supreme Court & 1.2986 & 1.5456 & $0.32(0.5740)$ \\
\hline Renominated by different president & 2.5292 & 2.7989 & $0.01(0.9055)$ \\
\hline Fixed state effects & Yes & & \\
\hline Pseudo $R^{2}$ & 0.0916 & & \\
\hline Log-likelihood & -1504.1562 & & \\
\hline$N^{\circ}$ & 277 & & \\
\hline
\end{tabular}

${ }^{a}$ The negative binomial regressions with incident-rate ratios are the same as used previously in Table 1 for the circuit court (Specification 6) with the exception that now we create a separate value for each variable when there is either a Republican or Democratic administration. No interactions are used for the fixed effects. Not all coefficients reported. $t$ statistics are shown in parentheses.

Note: Data sources are listed in Section III. Among the major data sources are: Lower Federal Court Confirmation Database, the Office of Legal Policy in the Department of Justice, biographies on federal judges from the Federal Judicial Center, the American Bar Association, Senate Judiciary Committee, Clinton Presidential Materials Project, and a Lexis-Nexis search.

president who first nominated the judge was a Republican and one for whether the nominating president was a Democrat. (There were essentially no statistically significant differences for Republican and Democratic district court nominees so those results are not reported.) The dummy variables for the different administrations are no longer included because of their collinearity with the Republican and Democratic dummies. The coefficients 
for most of the interactions are shown in Table 5. Among the statistically significant differences, African-American Democrats take about 40 percent less time to get through confirmation than African-American Republicans, Republicans who had previously served as federal judges took about 40 percent less time for confirmation than Democrats with the same background, and the only clerking background that seemed to make any difference was for nominees who had clerked for a federal district court judge.

So why has the length of the confirmation process increased over time? The administration dummies illustrate the increase, but they do not explain why it is occurring. Many of the variables, such as whether the Senate and presidency are controlled by the same party or when the nomination is made during a president's term, can explain some of the changes over time, but they do not explain the secular trend in the length of confirmations. One possibility is the increased polarization that has been occurring in the political process (e.g., Jones 2001; Theriault 2004). As the parties diverge more, it may be more difficult for the parties to work together or there might simply be more at stake in process.

Political scientists have used different measures of polarization, but they all tend to be fairly similar. They use different voting indexes of member of the House or Senate and take the differences between the median voting index for each party. Theriault (2004) provides a detailed survey of these indexes. Table 6 shows the results where measures of polarization are constructed based on the Americans for Democratic Action and DW-nominate voting indexes. ${ }^{28}$ Both measures cover the period from 1977 to 2003, and they both show that increased polarization increases the length of the confirmation process. A one percentage point change in the ADA index is associated with a 1 percent increase in the length of the confirmation process for district court judges and a three percentage point increase in the length of confirmations for circuit court judges. The impact from changes in the DW-nominate index is even larger, with a one percentage point change in the index producing a 4 percent change in the length of confirmations for district court judges and a 9 to 10 percent change in the length for circuit court judges.

\footnotetext{
${ }^{28}$ The ADA index is from <http://www.adaction.org?>. The DW scores are from $<$ http://www.voteview.com/dwnl.htm>.
} 
Table 6: Explaining the Number of Days Between Nomination and Confirmation $^{\mathrm{a}}$

\begin{tabular}{|c|c|c|c|c|c|c|}
\hline \multirow[b]{2}{*}{ Control Variable } & \multicolumn{3}{|c|}{ District Court Nominees } & \multicolumn{3}{|c|}{ Circuit Court Nominees } \\
\hline & 1 & 2 & 3 & 4 & 5 & 6 \\
\hline \multirow[t]{2}{*}{$\begin{array}{l}\text { ADA score measure of } \\
\text { polarization }\end{array}$} & $\begin{array}{c}1.013 \\
(8.30)\end{array}$ & $\begin{array}{r}1.012 \\
(7.98)\end{array}$ & $\begin{array}{c}1.012 \\
(7.55)\end{array}$ & $\begin{array}{l}1.03 \\
(9.27)\end{array}$ & $\begin{array}{r}1.032 \\
(10.06)\end{array}$ & $\begin{array}{r}1.029 \\
(7.88)\end{array}$ \\
\hline & 7 & 8 & 9 & 10 & 11 & 12 \\
\hline $\begin{array}{l}\text { DW-nominate score measure } \\
\text { of polarization }\end{array}$ & $\begin{array}{r}1.042 \\
(11.67)\end{array}$ & $\begin{array}{l}1.0383 \\
(10.97)\end{array}$ & $\begin{array}{r}1.042 \\
(10.33)\end{array}$ & $\begin{array}{l}1.0896 \\
(11.52)\end{array}$ & $\begin{array}{r}1.096 \\
(12.92)\end{array}$ & $\begin{array}{r}1.093 \\
(10.69)\end{array}$ \\
\hline
\end{tabular}

${ }^{a}$ The specifications are based on those shown in Table 1 with the exception that the presidential administration dummies are replaced with measures of polarization created from either the ADA index or DW-nominate scores. Using negative binomials with incident-rate ratios to estimate the number of days. $t$ statistics are shown in parentheses. For the $F$ statistics, the chi-square value is shown and the number in parentheses is the probability that the difference is statistically significant.

Note: Data sources are listed in Section III. Among the major data sources are: Lower Federal Court Confirmation Database, the Office of Legal Policy in the Department of Justice, biographies on federal judges from the Federal Judicial Center, the American Bar Association, Senate Judiciary Committee, Clinton Presidential Materials Project, and a Lexis-Nexis search.

\section{B. Confirmation Rate}

The regressions that examine the confirmation rate again also confirm the simple results shown in Figure 5. Table 7 uses the same specifications that were employed for Table 1 and provides mixed evidence on the changes in confirmation rates from Bush I to Bush II for district court nominees, while the probability consistently falls over the same period for circuit court nominees. The differences for the circuit court nominees again tend to be much more statistically significant than for the district court nominees. For example, using the logit specifications, the decline in district court confirmation rates from Clinton to Bush II was significant at the 17 percent level for an $F$ test, and the decline for the circuit courts for the same period was significant at better than the 1 percent level. (While the logit specification is emphasized here, I have included Cox and Weibull hazard models.)

As with the regressions on the length of the confirmation process, the most important factors are unified party control of the presidency and the Senate or having at least 10 years of experience as a lawyer, being renominated by a different president, with the probability of confirmation increas- 


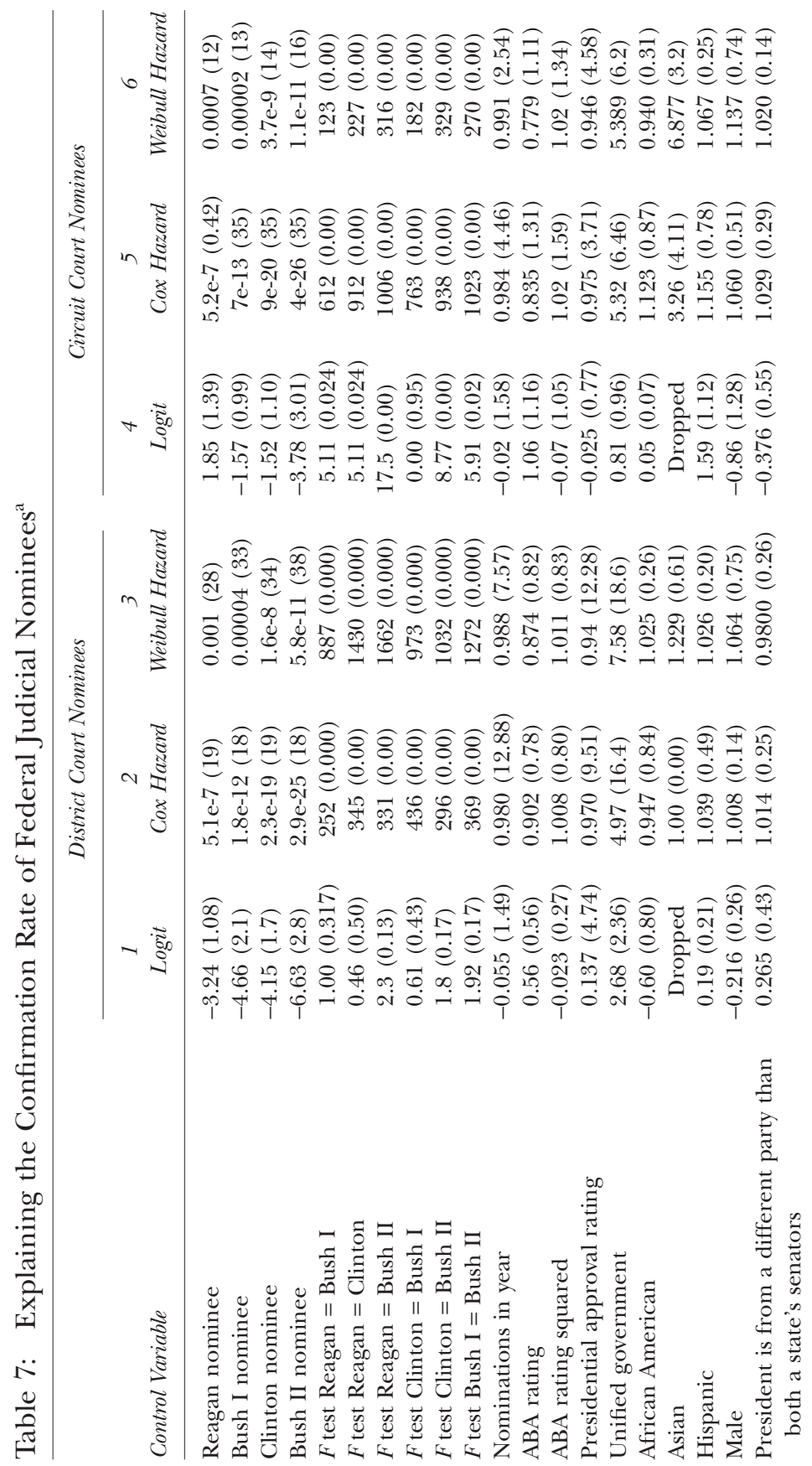




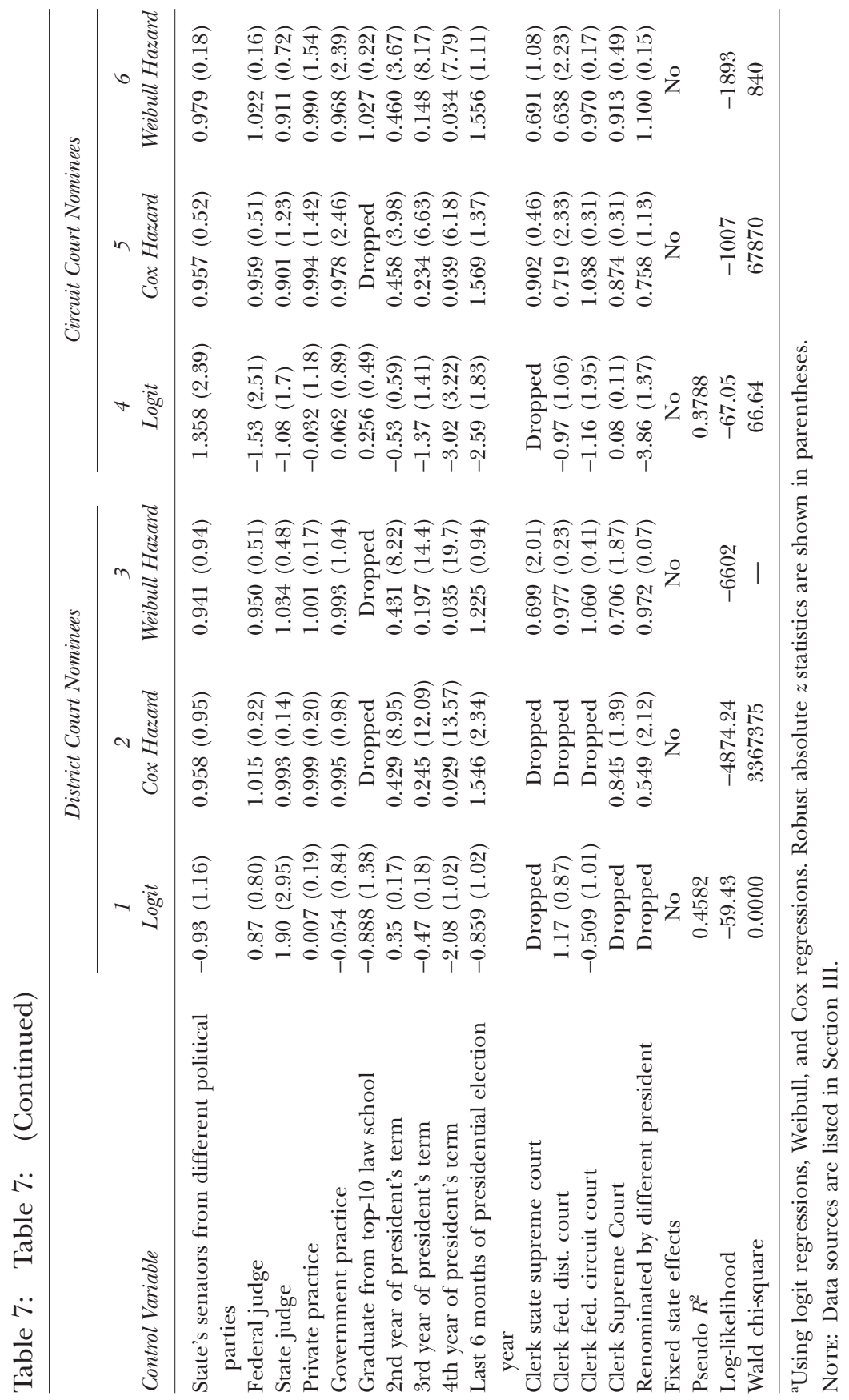


ing in both cases. Given the ABA's explicit rule of at least 10 years of experience, the number of years of experience seems to measure exactly what the ABA claims that it is focusing on (Hudson 2001). Being nominated during the last six months of a president's term consistently lowered the probability of being confirmed. Being nominated any time during the fourth year of a presidency makes it much more difficult to be confirmed for the circuit court, but does not have a statistically significant effect for district courts. African Americans faced the same odds of making it onto either the district or circuit courts as whites. There were some other surprising differences. Although being a state judge improved the odds of being confirmed for a district court, being a federal judge lowered the odds of getting onto the circuit court.

Estimates that paralleled Specifications 3 and 6 in Table 3 and used the Choi-Gulati and LLS indexes to measure the confirmation rate of higherquality judges did not produce results that converged. However, redoing the results using the two measures implies that more polarization is related to a lower probability of confirmation, but the effect is only statistically significant for circuit court judges. The ADA and DW-nominate measures of polarization imply that for circuit court nominees, a one percentage point increase in these indexes produces at least a 7 percent decline in the probability of confirmation.

Finally, one can break down the confirmation rates in the same way done in Table 5 so that each one of the variables is estimated separately for Republicans and Democrats. Again, there are many differences between what affects the confirmation process for Republicans and Democrats. For example, higher ABA ratings, presidential approval ratings, unified government, and graduating from a top-10 law school all are much more important in raising the confirmation rate for Democrats than for Republicans. Being a federal or state judge is more important for Republican nominees, and male Republicans are not as disadvantaged as male Democrats.

\section{Conclusion}

Major changes have occurred over time in the judicial confirmation process. The key factor seems to be that the more important the court, the greater the difficulty of having the person confirmed. Although the confirmation rates have fallen and the length of the confirmation process has lengthened 
dramatically, the ex-post measures of judicial quality of circuit court nominees based on citations or number of opinions or judicial independence have been decreasing over time. It is surprising how the ex ante measures of quality are so negatively correlated with the ex post measures. Where one goes to law school or if one has been on law review or whether one served as a judicial law clerk does not seem to do a very good job of predicting how well the person would do after they become a judge.

The most troubling results strongly indicate that circuit court judges who turn out to be the most successful judges, as measured by Choi and Gulati or Landes et al., faced the most difficult confirmation battles and the effect was large with a 1 percent increase in judicial quality increasing the length of the confirmation process by between 1 and 3 percent. Similarly, nominees who attended the best schools or served as clerks for the Supreme Court also faced very difficult nominations to the circuit court. One is tempted to tell bright young people desiring to make it to the circuit court to hide how bright they are.

Possibly, senators of the party opposite the president only really care about preventing the best judges from being on the circuit court because they will have the most impact. Choi and Gulati (2003:4, n. 6) cite those involved in the nomination process as saying that more capable judges are "better able to push the agendas . . .." Circuit courts can overrule strong district court judges. Opponents may accept weaker circuit court nominees because they are on three-judge panels and the brighter panel members will dominate the weaker judges. Alternatively, confirmation delays may prevent a judge from doing as much damage as he or she would do if the judge were appointed immediately and circuit court judges can create more of an impact than district court judges. ${ }^{29}$

The length of the confirmation process has increased during both recent Republican and Democratic presidencies while the opposition party controlled the Senate so it is difficult to blame the problem on any particular party. The major lengthening of the confirmation process for circuit court judges started in 1997 under Clinton when the Republicans controlled

\footnotetext{
${ }^{29} \mathrm{~A}$ well-known example of this appears to have occurred recently when a conservative nominee was delayed to the U.S. Court of Appeals for the Sixth Circuit so as to affect the outcome of Gratz $v$. Bollinger, a high-profile case on the constitutionality of an affirmative action program at the University of Michigan (Bolton 2004).
} 
the Senate. The process continued to accelerate out of control when Bush II was president and the Democrats controlled the Senate and has continued at a higher rate with the introduction of judicial filibusters during the 108th Congress.

The data suggest that lumping district and circuit court nominees together misses the different changes for the confirmation rates for the two types of courts. Why these patterns have been occurring is a matter of conjecture, but they are consistent with Congress being able to prevent a president from making the most important nominations while at the same time being able to point to an overall number (largely driven by district court nominees) that appears much more accommodating.

The article properly speaks only to the nomination and confirmation processes as they relate to federal judges. Future work could compare the experience of Article III judges and the experience of other presidential nominees (e.g., cabinet secretaries).

\section{REFERENCES}

Binder, Sarah A., \& Forrest Maltzman (2002) "Senatorial Delay in Confirming Federal Judges, 1947-1998," 46 American J. of Political Science 190.

Bell, Lauren Cohen (2002) "Senatorial Discourtesy: The Senate's Use of Delay to Shape the Federal Judiciary," September Political Research Q. 589.

Biskupic, Joan (2000) "Politics Snares Court Hopes of Minorities and Women," August 22 USA Today A1.

Bolton, Alexander (2004) "ACU Calls for Rehire of Miranda," April 14 The Hill 1.

Carney, Dan (1997) "More Challenges to Clinton Nominees Cause Judicial Stalemate," November Congressional Q. Weekly Report 2912.

Chicago Daily Law Bulletin (2000) "Illinois Judge Among 4 OK'd by Senate," October 4 Chicago Daily Law Bulletin 1.

Choi, Stephen, \& Mitu Gulati (2003) Choosing the Next Supreme Court Justice: An Empirical Ranking of Judicial Performance. Berkeley, CA: University of California at Berkeley, School of Law.

(2004) “A Tournament of Judges?” January California Law Rev 299.

- (2005) "Mr. Justice Posner?: Unpacking the Statistics," 2005 NYU Annual Survey of American Law 19.

Curry, George (2004) "GOP Ditching the Rules to Confirm Conservative Judges," September 15 Capitol Outlook 73.

Edwards III, George C., with Alec M. Gallup (1990) Presidential Approval: A Sourcebook. Baltimore, MD: Johns Hopkins University Press. 
Goldberg, Steven (2005) "Federal Judges and the Heisman Trophy," 2005 Florida State Univ. Law Rev.

Goldman, Sheldon (2003) "Assessing the Senate Judicial Confirmation Process: The Index of Obstruction and Delay," March-April Judicature 251.

Hartley, Roger (2000) “Gender, Maybe; Race, Seems Not," September 4 National J.

Hartley, R. E., \& L. M. Holmes (2002) "Increasing Senate Scrutiny of Lower Federal Court Nominees," 2002 Political Science Q. 259.

Hatch Orrin G., Jon Kyl, Strom Thurmond, Sam Brownback, Charles Grassley, \& Mike DeWine (2001) "Judicial Nominees Have Waited Long Enough, Senator," November 29 Washington Times.

Holland, Jesse J. (2000a) "Dem Holds Clinton Nominations," September 18 Associated Press.

- (2000b) "Senate Approves Last Clinton Judges," October 4 Associated Press.

Hudson, Audrey (2001) "Feminist Groups Target Bush Judicial Nominees,” December 11 Washington Times A1.

Jones, David R. (2001) "Party Polarization and Legislative Gridlock," March Political Research Q. 125.

Leahy, Patrick J. (2001) "Judicial Confirmations Going Faster Than Ever," November 26 Washington Times A18.

Linquist, Stefanie A., David A. Yalof, \& John A. Clark (2000) "The Impact of Presidential Appointments to the U.S. Supreme Court," 53 Political Research $Q$. 795.

Mann, William C. (2005) “Top Senate Democrat Cautions GOP on Rules,” January 17 Associated Press.

McCarty, Nolan, \& Rose Razaghian (1999). "Advice and Consent: Senate Responses to Executive Branch Nominations 1885-1996," 43 American J. of Political Science 1122.

McGinnis, John O., \& Michael B. Rappaport (forthcoming) "Supermajority Rules and the Judicial Confirmation Process," 26(2) Cardozo Law Rev.

Nixon, D. C., \& D. L. Goss (2001) "Confirmation Delay for Vacancies on the Circuit Court of Appeals,” 29 American Politics Q. 246.

Posner, Eric, \& Miguel De Figueiredo (2004) Is the International Court of Justice Biased? Univ. of Chicago Law School Working Paper.

Republican Policy Committee, U.S. Senate (2004) "The Assault on Judicial Nominations in the 108th Congress," September 28.

Ross, Sonya (2000) “Clinton Bypasses Congress, Appoints Civil Rights Chief," August 4 Associated Press.

Stolberg, Sheryl Gay (2004) "Despite G.O.P. Gain, Fight Over Judges Remains," November 5 New York Times 1.

Stratmann, Thomas, \& Jared Garner (2004) "Judicial Selection: Politics, Biases, and Constituency Demands," 118 Public Choice 251.

Sunstein, Cass R., David Schkade, \& Lisa Michelle Ellman (2003) Ideological Voting on Federal Courts of Appeals: A Preliminary Investigation. The Univ. of Chicago Law School John M. Olin Law \& Economics Working Paper No. 198. 
Theriault, Sean M. (2004) The Case of the Vanishing Moderates: Party Polarization in the Modern Congress. University of Texas Austin Working Paper.

Wall Street Journal (2004) “Editorial: Supreme Court Strategy," November 9 Wall Street J. A18. 